\title{
Advancements in Development of Chemical-Looping Combustion: A Review
}

\author{
He Fang, Li Haibin, and Zhao Zengli \\ The Renewable Energy and Gas Hydrate Key Laboratory of Chinese Academy of Sciences, Guangzhou Institute of Energy Conversion, \\ Chinese Academy of Sciences, Guangzhou 510640, China \\ Correspondence should be addressed to He Fang, hefangmj@hotmail.com
}

Received 9 June 2009; Accepted 18 August 2009

Recommended by B. Kulkarni

Chemical-looping combustion (CLC) is a novel combustion technology with inherent separation of greenhouse $\mathrm{CO}_{2}$. Extensive research has been performed on CLC in the last decade with respect to oxygen carrier development, reaction kinetics, reactor design, system efficiencies, and prototype testing. Transition metal oxides, such as $\mathrm{Ni}, \mathrm{Fe}, \mathrm{Cu}$, and $\mathrm{Mn}$ oxides, were reported as reactive species in the oxygen carrier particles. Ni-based oxygen carriers exhibited the best reactivity and stability during multiredox cycles. The performance of the oxygen carriers can be improved by changing preparation method or by making mixedoxides. The CLC has been demonstrated successfully in continuously operated prototype reactors based on interconnected fluidizedbed system in the size range of $0.3-50 \mathrm{~kW}$. High fuel conversion rates and almost $100 \% \mathrm{CO}_{2}$ capture efficiencies were obtained. The CLC system with two interconnected fluidized-bed reactors was considered the most suitable reactor design. Development of oxygen carriers with excellent reactivity and stability is still one of the challenges for CLC in the near future. Experiences of building and operating the large-scale CLC systems are needed before this technology is used commercially. Chemical-looping reforming (CLR) and chemical-looping hydrogen (CLH) are novel chemical-looping techniques to produce synthesis gas and hydrogen deserving more attention and research.

Copyright (c) 2009 He Fang et al. This is an open access article distributed under the Creative Commons Attribution License, which permits unrestricted use, distribution, and reproduction in any medium, provided the original work is properly cited.

\section{Introduction}

On February 2, 2007, the United Nations scientific panel studying climate change declared that the evidence of a warming trend is "unequivocal," and that human activity has "very likely" been the driving force in that change over the last 50 years [1]. According to the Intergovernmental Panel on Climate Change (IPCC) of the United Nations, the observed increase in globally averaged temperatures since the mid-twentieth century is very likely to have occurred due to the increase in anthropogenic greenhousegas concentrations that leads to the warming of the earth's surface and lower atmosphere. The greenhouse effect is the phenomenon where water vapor, carbon dioxide, methane, and other atmospheric gases absorb outgoing infrared radiation resulting in the raising of the temperature. In its turn, $\mathrm{CO}_{2}$ is essentially blamed to be the main factor causing the greenhouse effect because it is the most important anthropogenic greenhouse gas [2]. The concentration of $\mathrm{CO}_{2}$ in the atmosphere has risen to a value of $\sim 370 \mathrm{ppm}$ today, from the preindustrial value of $280 \mathrm{ppm}$ [3]. Combustion of fossil fuels releases a huge amount of carbon as carbon dioxide into the atmosphere. It was reported that fossil fuels fired power production contributes with one third of the total carbon dioxide release from fuels combustion worldwide [4]. It has been well known that increasing concentration of $\mathrm{CO}_{2}$ to the atmosphere may affect the climate of the earth. It is generally accepted that a reduction in emissions of greenhouse gases is necessary. At present, there are a number of $\mathrm{CO}_{2}$ capture processes as follows [5]:

(i) precombustion, in which the hydrocarbon fuels are decarbonized prior to combustion;

(ii) oxyfuel combustion, which uses pure oxygen separated from air;

(iii) postcombustion separation, which separates $\mathrm{CO}_{2}$ from the flues gases using different methods.

Most of these techniques have large energy penalty and high costs for separation of $\mathrm{CO}_{2}$ from the rest of the flue 


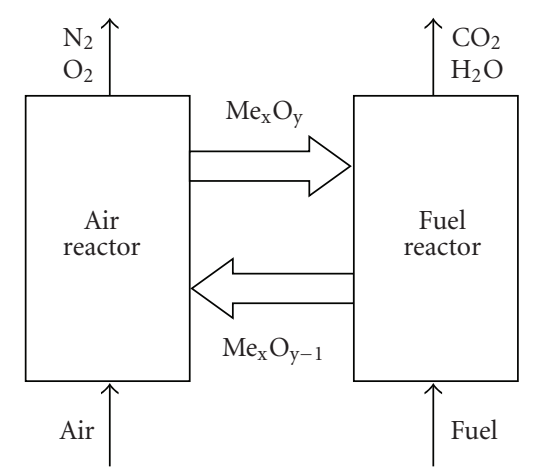

FIgURE 1: Chemical-looping combustion (CLC).

gas components, resulting in a significant decrease of the overall combustion efficiency and as a result in a price increase of the energy because of the cost for $\mathrm{CO}_{2}$ capture. Chemical-looping combustion (CLC) offers a solution for $\mathrm{CO}_{2}$ separation without energy penalty.

1.1. Chemical-Looping Combustion (CLC). The CLC uses a solid oxygen carrier to transfer the oxygen from the air to the fuel. The advantage with the technique compared to normal combustion is that $\mathrm{CO}_{2}$ and $\mathrm{H}_{2} \mathrm{O}$ are inherently separated from the other components of the flue gas, namely, $\mathrm{N}_{2}$ and unreacted $\mathrm{O}_{2}$, and thus no extra energy is needed for $\mathrm{CO}_{2}$ separation. The CLC system is composed of two reactors, an air and a fuel reactor, as shown in Figure 1.

In CLC, the solid oxygen carrier is circulated between the air and fuel reactors. The fuel is fed into the fuel reactor where it is oxidized by the lattice oxygen of the oxygen carriers according to

$$
\begin{aligned}
(2 \mathrm{n}+\mathrm{m}) & \mathrm{Me}_{\mathrm{x}} \mathrm{O}_{\mathrm{y}}+\mathrm{C}_{\mathrm{n}} \mathrm{H}_{2 \mathrm{~m}} \\
& \longrightarrow(2 \mathrm{n}+\mathrm{m}) \mathrm{Me}_{\mathrm{x}} \mathrm{O}_{\mathrm{y}-1}+\mathrm{mH}_{2} \mathrm{O}+\mathrm{nCO}_{2},
\end{aligned}
$$

where $\mathrm{M}_{\mathrm{y}} \mathrm{O}_{\mathrm{x}}$ is the fully oxidized oxygen carrier and $\mathrm{M}_{\mathrm{y}} \mathrm{O}_{\mathrm{x}-1}$ is the oxygen carrier in the reduced form which could be a metal or a metal oxide with lower oxygen content. The exit stream from the fuel reactor contains only $\mathrm{CO}_{2}$ and water vapor. The pure $\mathrm{CO}_{2}$ can be readily recovered by condensing water vapor, eliminating the need of an additional energy for $\mathrm{CO}_{2}$ separation. The water-free $\mathrm{CO}_{2}$ can be sequestrated or used for other purpose.

Once fuel oxidation completed the reduced metal oxide $\mathrm{M}_{\mathrm{y}} \mathrm{O}_{\mathrm{x}-1}$ is transported to the air reactor where it is reoxidized according the reaction

$$
\mathrm{Me}_{\mathrm{x}} \mathrm{O}_{\mathrm{y}-1}+\frac{1}{2} \mathrm{O}_{2} \longrightarrow \mathrm{Me}_{\mathrm{x}} \mathrm{O}_{\mathrm{y}} .
$$

The flue gas stream from the air reactor will have a high temperature and contain $\mathrm{N}_{2}$ and some unreacted $\mathrm{O}_{2}$. This stream could be expanded through a gas turbine to produce electricity. After energy recovered, these gases can be released to the atmosphere with minimum negative environmental impact. The reaction between the fuel and oxygen carrier in the fuel reactor may be endothermic as well as exothermic depending on the metal oxide used, while the reaction in the air reactor is always exothermic. The CLC does not bring any enthalpy gains, thus, the total heat evolved in these two reactions is the same as that of normal combustion in air. Its main advantage, however, is in the inherent separation of both $\mathrm{CO}_{2}$ and $\mathrm{H}_{2} \mathrm{O}$ from the flue gases. In addition, since air and fuel go through two separated reactors and combustion takes place without a flame, $\mathrm{NO}_{\mathrm{x}}$ formation should be avoided [6]. From the point of view of environmentalfriendly characterizations, CLC has attracted wide attention and extensive investigation in the past a few years. This work will present an overview of the work which has been conducted about the development and investigation on CLC.

\section{Oxygen Carrier Development}

When the CLC was firstly proposed by Richter and Knoche [7], the selection of the oxygen carrier was considered as one of the most important components of the CLC process. The oxygen carrier particles are a cornerstone in the CLC technique. Important properties for oxygen carriers are high reactivity in both reduction by fuel gas and oxidation by oxygen in the air, as well as high resistance to attrition, fragmentation, and agglomeration. Additionally, it is also an advantage if the metal oxide is cheap and environmentally friendly. Briefly, important criteria for a good oxygen carrier are the following:

(i) high reactivity with fuel and air;

(ii) low fragmentation and attrition, as well as low tendency for agglomeration;

(iii) low production cost and environmentally benign;

(iv) be fluidizable and stable under repeated reduction/oxidation cycles at high temperature.

A number of different transition-state metals and their corresponding oxides have been investigated in literature as possible candidates: $\mathrm{Cu}, \mathrm{Cd}, \mathrm{Ni}, \mathrm{Mn}, \mathrm{Fe}$, and Co. Figure 2 presents the mass ratio of active oxygen for different systems of metal oxides.

Generally, these metal oxides are combined with an inert which acts as a porous support providing a higher surface area for reaction, as a binder for increasing the mechanical strength and attrition resistance, and additionally, as an ion conductor enhancing the ion permeability in the solid particles [8]. However, $\mathrm{Al}_{2} \mathrm{O}_{3}, \mathrm{SiO}_{2}, \mathrm{TiO}_{2}, \mathrm{ZrO}_{2}, \mathrm{NiAl}_{2} \mathrm{O}_{4}$, and $\mathrm{MgAl}_{2} \mathrm{O}_{4}$ are usually used as the inert binder which was proven to have the ability to increase the reactivity, durability, and fluidizability of the oxygen carrier particles. The inert materials are believed to enhance positive properties among which the most important are to maintain the pore structure inside the particle and inhibit migration of the metals, which could lead to sintering of oxygen carrier particles. In the last decade, a number of researches on oxygen carriers for chemical-looping combustion have been performed. The major affiliations have been Chalmers University of Technology in Göteborg, Sweden, CSIC in Zaragoza, Spain, Tokyo Institute of Technology in Japan, and Korea Institute of Energy Research. 


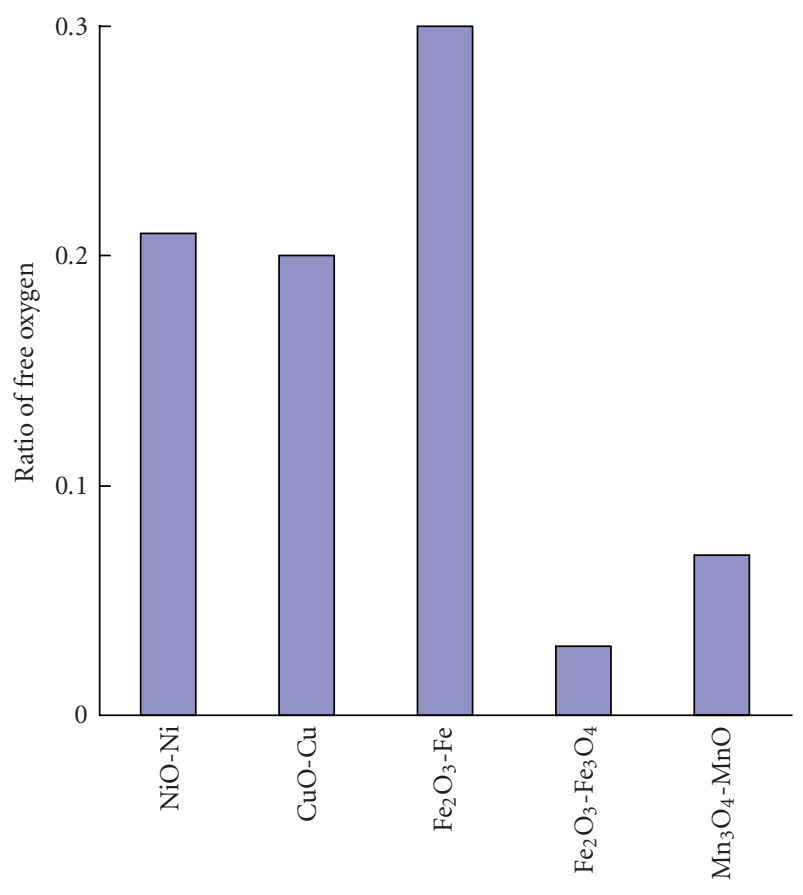

FIgURE 2: Mass ratio of active oxygen for different metal oxides.

2.1. NiO-Based Oxygen Carriers. Ni-based oxygen carriers can be used at high temperatures of $900-1100^{\circ} \mathrm{C}$ in a CLC process with full $\mathrm{CH}_{4}$ conversion although thermodynamic limitations result in a small amount of $\mathrm{CO}$ and $\mathrm{H}_{2}$ in the outlet gas of the fuel reactor [9]. Pure $\mathrm{NiO}$ without doping inert binder used as looping material in CLC has been studied and compared with NiO/YSZ (yttria-stabilized zirconia) by using hydrogen or natural gas as the fuel [6]. As a result, the $\mathrm{NiO} / \mathrm{YSZ}$ particle permitted extremely fast oxidation compared to the pure $\mathrm{NiO}$ sample. The addition of YSZ to $\mathrm{NiO}$ gives a high solid diffusivity for the oxide ion especially at high temperature and high porosity turns out to be a crucial feature that YSZ played an important role in increasing the oxidation rate. The performance of NiO/YSZ mixture used as oxygen carrier in CLC was investigated by other researchers [10-14]. It was shown that NiO/YSZ displayed excellent reactivity and regenerability. However, the price of YSZ is higher in comparison to other inerts.

Another inert binder and support material which was used in $\mathrm{NiO}$-based oxygen carriers is $\mathrm{Al}_{2} \mathrm{O}_{3}$. It was shown that the solid particles of $\mathrm{NiO} / \mathrm{Al}_{2} \mathrm{O}_{3}$ had good reactivity and high mechanical strength [13]. Another advantage of using $\mathrm{Al}_{2} \mathrm{O}_{3}$ as inert binder is that it is much cheaper than YSZ powder. Therefore, $\mathrm{Al}_{2} \mathrm{O}_{3}$ has attracted wide attention due to its favorable fluidization properties thermal stability, and low cost [15-18]. It is noted that a part of $\mathrm{NiO}$ is converted to form metal aluminum spinel compounds, $\mathrm{NiAl}_{2} \mathrm{O}_{4}$, via solid-state reaction with $\mathrm{Al}_{2} \mathrm{O}_{3}$ in the course of the sintering process [19]. The $\mathrm{NiAl}_{2} \mathrm{O}_{4}$ is inert or reacts very slowly with fuels or oxygen, therefore, the active metal oxide is added in excess to obtain an $\mathrm{NiO} / \mathrm{NiAl}_{2} \mathrm{O}_{4}$ of desired mass ratio to compensate for the loss of nickel as nickel aluminate [20]. $\mathrm{NiAl}_{2} \mathrm{O}_{4}$ is kept even in the cyclic reactions. It plays the role in keeping the mechanical strength of the particle. To inhibit the interaction between $\mathrm{NiO}$ and $\mathrm{Al}_{2} \mathrm{O}_{3}$, Gayán et al. prepared $\mathrm{NiO}$-based oxygen carriers with modified $\mathrm{Al}_{2} \mathrm{O}_{3}$ via thermal treatment or chemical deactivation with $\mathrm{Mg}$ or $\mathrm{Ca}$ oxides [21]. Thermal treatment of $\gamma-\mathrm{Al}_{2} \mathrm{O}_{3}$ at $1150^{\circ} \mathrm{C}$ produced the phase transformation to $\alpha-\mathrm{Al}_{2} \mathrm{O}_{3}$. The chemical pretreatment consisted in precoating the $\gamma$ $\mathrm{Al}_{2} \mathrm{O}_{3}$ support with $\mathrm{MgO}$ or $\mathrm{CaO}$. The precoating was carried out by dry impregnation on $\gamma-\mathrm{Al}_{2} \mathrm{O}_{3}$ with $\mathrm{Mg}$ or $\mathrm{Ca}$ nitrate solutions and forming the corresponding aluminates by sintering at high temperature. $\mathrm{Ni}$-based oxygen carriers prepared on $\alpha-\mathrm{Al}_{2} \mathrm{O}_{3}, \mathrm{MgAl}_{2} \mathrm{O}_{4}$, or $\mathrm{CaAl}_{2} \mathrm{O}_{4}$ as support showed very high reactivity and high methane combustion selectivity to $\mathrm{CO}_{2}$ and $\mathrm{H}_{2} \mathrm{O}$ because the interaction between the $\mathrm{NiO}$ and the support was minimized.

As $\mathrm{NiAl}_{2} \mathrm{O}_{4}$ is formed during the sintering when $\mathrm{Al}_{2} \mathrm{O}_{3}$ is used as support, a few of researchers have proposed using $\mathrm{NiAl}_{2} \mathrm{O}_{4}$ as a support and binder instead of $\mathrm{Al}_{2} \mathrm{O}_{3}$ [2225]. As the results, the $\mathrm{NiO} / \mathrm{NiAl}_{2} \mathrm{O}_{4}$ particles displayed good reactivity and selectivity of oxidation of methane to $\mathrm{CO}_{2}$ and $\mathrm{H}_{2} \mathrm{O}$. The particles showed an increase in mechanical strength, no sign of deactivation, and no change in chemical composition after multicyclic chemical-looping combustion. Linderholm et al. [26] studied the performance of $\mathrm{NiO} / \mathrm{NiAl}_{2} \mathrm{O}_{4}$ oxygen carrier in a $10 \mathrm{~kW}$ reactor for 160 hours. They found that a conversion of natural gas to $\mathrm{CO}_{2}$ and $\mathrm{H}_{2} \mathrm{O}$ of approximately $99 \%$ was accomplished. No decrease in reactivity was seen during the test period. According to the previous investigations, $\mathrm{NiO} / \mathrm{NiAl}_{2} \mathrm{O}_{4}$ oxygen carrier was considered as one of the most promising oxygen carriers for CLC due to its good reactivity, cyclic reaction ability, and high bearing temperature of above $900^{\circ} \mathrm{C}$.

It was found that the presence of $\mathrm{Mg}$ in $\mathrm{Ni}-\mathrm{Al}-\mathrm{O}$ mixed oxides minimizes the sintering of the $\mathrm{NiO}$ and stabilizes the $\mathrm{Ni}^{2+}$ in the oxide phase [23]. Zafar et al. [27] found that there was no or a limited interaction between the support and the active phase in the course of cycling experiments using a $\mathrm{NiO} / \mathrm{MgAl}_{2} \mathrm{O}_{4}$ as oxygen carrier. Therefore, $\mathrm{MgAl}_{2} \mathrm{O}_{4}$ has been considered as a support for $\mathrm{NiO}$ to avoid aluminate formation. Johansson et al. [28] tested a chemical-looping combustor of $300 \mathrm{~W}$ using an oxygen carrier composed of $60 \mathrm{wt} \% \mathrm{NiO}$ and $40 \mathrm{wt} \% \mathrm{MgAl}_{2} \mathrm{O}_{4}$. It was found that the $\mathrm{NiO} / \mathrm{MgAl}_{2} \mathrm{O}_{4}$ particle gave a high conversion of the natural gas. No methane was detected out in the exit gas out of the fuel reactor, and the fraction of $\mathrm{CO}$ varied between 0.5 and $3 \%$. Zafar et al. [29] determined the reactivity of the oxygen carrier composed of $60 \mathrm{wt} \% \mathrm{NiO}$ with $40 \mathrm{wt} \% \mathrm{MgAl}_{2} \mathrm{O}_{4}$. The reactivity was investigated in a TGA at $800-1000^{\circ} \mathrm{C}$ using $5-20 \% \mathrm{CH}_{4}$ as a fuel gas for reduction and $3-15 \% \mathrm{O}_{2}$ as an oxidizing gas for oxidation. The oxygen carrier showed very high reactivity during reduction and oxidation. The reaction rate was a function of the reacting gas concentration and temperature both in reduction and oxidation reactions. However, it was found that the conversion of particles for the reduction reaction was very low at $800-850^{\circ} \mathrm{C}$, which suggested that it may not be feasible to use this oxygen carrier at lower temperature in a CLC system. Johansson et al. found that $\mathrm{NiO} / \mathrm{MgAl}_{2} \mathrm{O}_{4}$ demonstrated several advantages at elevated temperatures, that is, higher methane conversion, 
higher selectivity to reforming, and less tendency for carbon formation compared with $\mathrm{NiO} / \mathrm{NiAl}_{2} \mathrm{O}_{4}$ [30]. In addition, several other researchers prepared $\mathrm{NiO} / \mathrm{MgAl}_{2} \mathrm{O}_{4}$ oxygen carriers and investigated their performances for CLC [3133].

A few of researchers have tried to use $\mathrm{SiO}_{2}, \mathrm{TiO}_{2}$, bentonite, or $\mathrm{ZrO}_{2}$ as support in the Ni-based oxygen carrier particles for CLC $[34,35]$. It was found that the oxygen carriers supported on $\mathrm{Al}_{2} \mathrm{O}_{3}$ or bentonite produced higher reactivity than those on $\mathrm{TiO}_{2}$. Moreover, the reactivity of the metal oxide particles increases with increasing temperature and the amount of NiO. Natural titania contained mineral, rutile, was reported to be used as support and binder in nickel-based oxygen carrier [36]. The results revealed that the reactions are fast, as $\mathrm{CO}_{2}$ is the only compound detected in the outlet gas of the reduction stage. As the reaction proceeds, however, the thermal decomposition of methane appears as a side reaction which competes for methane consumption with the main reaction of the CLC. Zafar et al. [27] observed that the reactivity of $\mathrm{NiO} / \mathrm{SiO}_{2}$ decreased as a function of the cycle number at $950^{\circ} \mathrm{C}$ but was avoided below $850^{\circ} \mathrm{C}$. The same research group reported that $\mathrm{NiO} / \mathrm{SiO}_{2}$ displayed high selectivity toward $\mathrm{H}_{2}$ during the later stages of reduction in chemical-looping reforming [37].

Generally speaking, the reactivity of the four most studied supported oxygen carriers is in the descending order of $\mathrm{NiO}>\mathrm{CuO}>\mathrm{Mn}_{2} \mathrm{O}_{3}>\mathrm{Fe}_{2} \mathrm{O}_{3}$ [38] although this order depends on how the oxide is supported. Therefore, Ni-based oxygen carriers are believed the most promising oxygen carrier candidate for CLC.

2.2. $\mathrm{CuO}$-Based Oxygen Carriers. Among the possible metal oxides, $\mathrm{CuO}$ has the highest oxygen transport capacity [39]. In the CLC system, the reaction between fuel and metal oxide in the fuel reactor may be endothermic as well as exothermic depending on the oxygen carrier used, while the reaction in the air reactor is always exothermic. When $\mathrm{CuO}$ is used as oxygen carrier, however, both the reactions in fuel and air reactors are exothermic. Briefly, $\mathrm{Cu}$-based oxygen carriers have several advantages: (1) $\mathrm{CuO}$ has a high oxygen transport capacity, allowing system operating with lower solid flow rates circulating between the fuel reactor and air reactor [40]; (2) the reactions both reduction and oxidation are exothermic avoiding the need of heat supply in the reduction reactor [41]; (3) $\mathrm{CuO}$ reduction is favored thermodynamically to reach complete conversion of gaseous hydrocarbon fuels into $\mathrm{CO}_{2}$ and $\mathrm{H}_{2} \mathrm{O}$ [39]; (4) $\mathrm{CuO}$ is one of the cheapest materials that can be used for CLC [42]; (5) $\mathrm{Cu}$-based carriers are highly reactive in both reduction and oxidation cycles, which reduces the solids inventory in the system.

de Diego et al. [43] reported that the reaction rate of pure $\mathrm{CuO}$ decreased quickly with the increasing number of cycles and after three cycles of reaction the reactivity of the pure $\mathrm{CuO}$ was extremely low, reaching conversion of only $10 \%$ in more than 20 minutes. Therefore, to obtain better $\mathrm{Cu}$-based oxygen carrier, an inert binder needs to be added into the $\mathrm{CuO}$. They examined the effects of the carrier composition and preparation method on the property of $\mathrm{Cu}$-based oxygen carriers. It was concluded that, to obtain $\mathrm{Cu}$-based oxygen carriers with high reduction and oxidation reaction rates while maintaining their mechanical properties for a high number of successive reduction-oxidation cycles, the only effective preparation method was impregnation on a support. The presence of a binder plays the role as an oxygen-permeable material and as a material to enhance the mechanical strength of the particle for cyclic use and against abrasion. Mattisson et al. [44] prepared $\mathrm{CuO} / \mathrm{Al}_{2} \mathrm{O}_{3}$ oxygen carriers by means of dry impregnation and investigated its reactivity. It was observed that the reduction rate is fast at all temperature in the range $750-950^{\circ} \mathrm{C}$ for $\mathrm{CuO} / \mathrm{Al}_{2} \mathrm{O}_{3}$. Minor amounts of $\mathrm{CuO}$ were decomposed to $\mathrm{Cu}_{2} \mathrm{O}$ during the inert period following the oxidation period at $950^{\circ} \mathrm{C}$. de Diego et al. [45] found that $\mathrm{CuO} / \mathrm{Al}_{2} \mathrm{O}_{3}$ oxygen carriers with a $\mathrm{CuO}$ content lower than $10 \mathrm{wt} \%$ never agglomerated in the fluidized bed and that the one with a $\mathrm{CuO}$ content greater than $20 \mathrm{wt} \%$ always agglomerated. In addition, the reactivity of the $\mathrm{CuO} / \mathrm{Al}_{2} \mathrm{O}_{3}$ oxygen carriers, during the reduction and oxidation reactions, was high and not affected by the number of cycles carried out in the fluidized bed. Complete $\mathrm{CH}_{4}$ conversion to $\mathrm{CO}_{2}$ and $\mathrm{H}_{2} \mathrm{O}$ during most of the reduction period was obtained. Chuang et al. [46] developed Cu-based oxygen carrier and studied the performance for burning solid fuels using CLC. It was found that carriers made by mechanical mixing and wet-impregnation were rejected, because they agglomerated and exhibited low reactivity. Co-precipitated carriers, however, did not agglomerate and showed a high reactivity after 18 cycles of operation. The effect of the operating conditions, such as oxygen carrier-tofuel ratio, fuel gas velocity, oxygen carrier particle size, and fuel reactor temperature, on fuel conversion was analyzed working with a $\mathrm{CuO} / \mathrm{Al}_{2} \mathrm{O}_{3}$ oxygen carrier prepared by dry impregnation in a $10 \mathrm{~kW}_{\text {th }}$ pilot fluidized-bed reactor [47]. It was found that the most important parameter affecting the $\mathrm{CH}_{4}$ conversion was the oxygen carrier-to-fuel ratio. Complete methane conversion, without $\mathrm{CO}$ or $\mathrm{H}_{2}$ emissions, was obtained with this oxygen carrier working at $800^{\circ} \mathrm{C}$ and oxygen carrier-to-fuel ratios of $>1.4$.

$\mathrm{SiO}_{2}$ was studied as well as an oxygen carrier support material for copper-based oxygen carriers. Corbella et al. [48] studied the performance of a copper oxide silica-supported oxygen carrier in a 20-cycle test of chemical-looping of methane in a fixed-bed reactor at $800^{\circ} \mathrm{C}$ and atmospheric pressure. It was revealed that the reduction reaction rate is fast and highly selective to $\mathrm{CO}_{2}$ formation, and $\mathrm{CO}$ emissions are very low, only yielded at the end of the reduction stage. In the 20-cycle test neither performance decay nor mechanical degradation of the oxygen carrier has been observed. Son et al. [49] found that the oxygen particles supported on $\mathrm{SiO}_{2}$ exhibit worse reactivity than those on $\mathrm{Al}_{2} \mathrm{O}_{3}$. In addition, $\mathrm{ZrO}_{2}, \mathrm{TiO}_{2}$, and bentonite were also studied as the inert support for copper-based oxygen carrier [50-52].

2.3. $\mathrm{Fe}_{2} \mathrm{O}_{3}$-Based Oxygen Carriers. High reactivities in both reduction by fuel and oxidation by oxygen in the air, as well as high resistance to attrition, fragmentation, and agglomeration are the important properties for oxygen carriers. 
In addition, it is also an advantage if the oxygen carrier is inexpensive and environmentally friendly. Advantages with iron-based oxygen carriers are the environmental compatibility of its oxides magnetite $\left(\mathrm{Fe}_{3} \mathrm{O}_{4}\right)$, hematite $\left(\mathrm{Fe}_{2} \mathrm{O}_{3}\right)$, and wustite $(\mathrm{FeO})$ and the lower price of iron oxides than other oxides such as nickel oxide $(\mathrm{NiO})$ and copper oxide $(\mathrm{CuO})$ [53]. In view of the availability, low price, as well as environmental safe of iron oxides, has attracted wide attention as oxygen carriers for using in CLC. It was confirmed that the reduction kinetics from hematite to magnetite $\left(\mathrm{Fe}_{2} \mathrm{O}_{3} \rightarrow \mathrm{Fe}_{3} \mathrm{O}_{4}\right)$ is the fastest step with the subsequent steps, the steps of magnetite to ferrous oxide $\left(\mathrm{Fe}_{3} \mathrm{O}_{4} \rightarrow \mathrm{FeO}\right)$ and ferrous oxide to iron $(\mathrm{FeO} \rightarrow \mathrm{Fe})$ being much slower. The subsequent steps were considered to be feasible for the chemical-looping reforming (CLR).

Pure $\mathrm{Fe}_{2} \mathrm{O}_{3}$ was studied as oxygen carrier at $720-800^{\circ} \mathrm{C}$ and demonstrated excellent chemical stability and no loss of activity with cyclic redox. However, the same particles began to agglomerate at $900^{\circ} \mathrm{C}$ though the agglomeration rate was slow [54]. Previous researchers found that the agglomeration and breakage of the particles could be avoided by adding $\mathrm{Al}_{2} \mathrm{O}_{3}$ into the particles [55]. Ishida et al. [56] prepared $\mathrm{Fe}_{2} \mathrm{O}_{3} / \mathrm{Al}_{2} \mathrm{O}_{3}$ composite particles and evaluated their applicability as solid looping materials of the chemical-looping combustor. They found that two solid solutions, hematite(ss) and corundum(ss), were formed in $\mathrm{Fe}_{2} \mathrm{O}_{3} / \mathrm{Al}_{2} \mathrm{O}_{3}$ composite particles at temperatures above $1000^{\circ} \mathrm{C}$. The mechanical strength of the $\mathrm{Fe}_{2} \mathrm{O}_{3} / \mathrm{Al}_{2} \mathrm{O}_{3}$ particles was improved by increasing the content of corundum(ss). Cho et al. [57] compared the iron-, nickel-, copper-, and manganese-based oxygen carriers for chemical-looping combustion. It was observed that oxygen carriers based on nickel, copper, and iron showed high reactivity enough to be feasible for CLC system. However, samples of the $\mathrm{Fe}_{2} \mathrm{O}_{3} / \mathrm{Al}_{2} \mathrm{O}_{3}$ showed signs of agglomeration. The same research group developed $\mathrm{Fe}_{2} \mathrm{O}_{3}$-based oxygen carriers together with various inerts such as $\mathrm{Al}_{2} \mathrm{O}_{3}, \mathrm{ZrO}_{2}, \mathrm{TiO}_{2}$, and $\mathrm{MgAl}_{2} \mathrm{O}_{4}$ finding that $\mathrm{Fe}_{2} \mathrm{O}_{3} / \mathrm{Al}_{2} \mathrm{O}_{3}$ exhibited good reactivity [58]. In our previous work, Fe-based oxygen carrier composed of $80 \mathrm{wt} \% \mathrm{Fe}_{2} \mathrm{O}_{3}$ with $20 \mathrm{wt} \% \mathrm{Al}_{2} \mathrm{O}_{3}$ has been prepared by impregnation methods [59]. The $\mathrm{Fe}_{2} \mathrm{O}_{3} / \mathrm{Al}_{2} \mathrm{O}_{3}$ oxygen carrier showed good reactivity in 20-cycle redox tests in a TGA reactor. However, $85 \%$ of the $\mathrm{CH}_{4}$ was converted to $\mathrm{CO}_{2}$ and $\mathrm{H}_{2} \mathrm{O}$ during most of the reduction periods with minor formation of $\mathrm{CO}$ and $\mathrm{H}_{2}$. Abad et al. [60] investigated the performance of ironbased oxygen carrier in a continuously operating laboratory CLC unit, consisting of two interconnected fluidized beds using natural gas or syngas as fuel. The combustion of fuel gas was stable during the operation of the reactor. The combustion efficiencies of syngas and natural gas reached $99 \%$ and up to $94 \%$, respectively. The reactivity and the crushing strength of the oxygen carrier particles were not affected significantly during operation. Agglomeration and carbon deposition were not observed and no mass loss of the solids inventory was detected. It is clear that attrition and agglomeration of $\mathrm{Fe}_{2} \mathrm{O}_{3} / \mathrm{Al}_{2} \mathrm{O}_{3}$ oxygen carrier can be controlled at very low level if it is operated under proper conditions. Therefore, $\mathrm{Fe}_{2} \mathrm{O}_{3} / \mathrm{Al}_{2} \mathrm{O}_{3}$ oxygen carrier is one of the promising candidates for CLC.
Similar to $\mathrm{Ni}$ - and $\mathrm{Cu}$-based oxygen carriers, other materials, such as YSZ, $\mathrm{MgAl}_{2} \mathrm{O}_{4}, \mathrm{TiO}_{2}$, and $\mathrm{SiO}_{2}$, were reported being used as binder and support in the oxygen carrier particles. Johansson et al. [61] suggested that the $\mathrm{Fe}_{2} \mathrm{O}_{3} / \mathrm{MgAl}_{2} \mathrm{O}_{4}$ oxygen carrier showed best reactivity among the iron oxides supported on six different inert materials. As for this kind of oxygen carrier, the one containing $60 \mathrm{wt} \% \mathrm{Fe}_{2} \mathrm{O}_{3}$ and $40 \mathrm{wt} \% \mathrm{MgAl}_{2} \mathrm{O}_{4}$ sintered at $1100^{\circ} \mathrm{C}$ exhibited reasonable crushing strength and resistance toward agglomeration and fragmentation. Leion et al. [62] studied the chemical-looping combustion of petroleum coke using $\mathrm{Fe}_{2} \mathrm{O}_{3} / \mathrm{MgAl}_{2} \mathrm{O}_{4}$ as oxygen carrier. It was revealed that the particles $\mathrm{Fe}_{2} \mathrm{O}_{3} / \mathrm{MgAl}_{2} \mathrm{O}_{4}$ reacted rapidly with intermediate gasification products such as $\mathrm{CO}$ and $\mathrm{H}_{2}$. Therefore, the presence of an oxygen carrier enhanced the gasification of petroleum coke. $\mathrm{TiO}_{2}$ was also proposed being used as inert and support of the iron-base oxygen carriers. Corbella and Palacios [63] found that the available oxygen of $\mathrm{Fe}_{2} \mathrm{O}_{3} / \mathrm{TiO}_{2}$ particles for methane combustion in the reduction stage was lower than expected due to the active phase interacts with the support forming $\mathrm{FeTiO}_{3}$ ilmenite. Similar results were observed for $\mathrm{Fe}_{2} \mathrm{O}_{3} / \mathrm{SiO}_{2}$ oxygen carrier, the formation of $\mathrm{Fe}_{2} \mathrm{SiO}_{4}$ reduced the reactivity of the $\mathrm{Fe}_{2} \mathrm{O}_{3} / \mathrm{TiO}_{2}$ particles [37].

Natural iron ores, such as hematite and ilmenite, have also considered as oxygen carriers for CLC, especially for solid fuels CLC. The work in [64] reported the feasibility of using ilmenite as oxygen carrier in CLC. It was found that ilmenite is an attractive and inexpensive oxygen carrier for CLC. The ilmenite particles showed no decrease in reactivity after 37 cycles of redox in a laboratory fluidizedbed reactor system. Ilmenite gave high conversion of $\mathrm{CO}$ and moderate conversion of $\mathrm{CH}_{4}$. Berguerand and Lyngfelt [65] investigated the CLC process of petroleum coke in a $10 \mathrm{~kW}_{\text {th }}$ chemical-looping combustor. The petroleum conversion reached higher figures of 66 to $78 \%$. Low loss of noncombustible fines from the system indicated very low attrition of the ilmenite particles. The $\mathrm{CO}_{2}$ capture ranged from 60 to $75 \%$. Natural hematite was also studied being used as oxygen carrier in CLC with $\mathrm{CH}_{4}$ and air at $950^{\circ} \mathrm{C}$ [66]. It was found that the majority of $\mathrm{CH}_{4}$ was converted to $\mathrm{CO}_{2}$ with some small formation of $\mathrm{CO}$ during the reduction period. For the first reduction period the degree of methane conversion was about $62 \%$. Clear breakage on the surface of the reacted particles was observed due to the chemical reactions occurring.

2.4. $\mathrm{Mn}_{3} \mathrm{O}_{4}$-Based Oxygen Carriers. Nickel-, copper-, and iron-oxides have been widely investigated in previous literatures as possible candidates for CLC. Manganese oxides, however, have been reported limitedly being used as oxygen carriers of CLC. Adánez et al. [8] developed manganese oxides on five different inert materials, such as $\mathrm{Al}_{2} \mathrm{O}_{3}$, Sepiolite, $\mathrm{SiO}_{2}, \mathrm{TiO}_{2}$, and $\mathrm{ZrO}_{2}$. In their study, $\mathrm{Al}_{2} \mathrm{O}_{3}$, Sepiolite, $\mathrm{SiO}_{2}$, and $\mathrm{TiO}_{2}$ were found being unsuitable as support for manganese-based oxygen carriers. $\mathrm{ZrO}_{2}$ was found to be the best inert material for manganese oxides in the view of reactivity and strength. Mattisson et al. [44] prepared $\mathrm{Mn}_{3} \mathrm{O}_{4} / \mathrm{Al}_{2} \mathrm{O}_{3}$ oxygen carrier and investigated its 
reactivity. It was found that $\mathrm{Mn}_{3} \mathrm{O}_{4} / \mathrm{Al}_{2} \mathrm{O}_{3}$ appeared poor reactivity mostly due to the formation of $\mathrm{MnAl}_{2} \mathrm{O}_{4}$ during sintering, which does not react with the fuels and oxygen. Cho et al. [57] also studied the performance of $\mathrm{Mn}_{2} \mathrm{O}_{4}$ supported on $\mathrm{Al}_{2} \mathrm{O}_{3}$. Again the reactivity was found to be poor because of the same reason. Johansson et al. [67] synthesized manganese-based oxygen carriers together with pure $\mathrm{ZrO}_{2}$ and $\mathrm{ZrO}_{2}$ stabilized with $\mathrm{CaO}, \mathrm{MgO}$, and $\mathrm{CeO}_{2}$. They found that almost all investigated particles exhibited high reactivity and limited physical changes during the cyclic reactions. The effect of the number of cyclic redox reactions on the reactivity of the all four samples was not clear. The one stabilized with $\mathrm{MgO}$ showed the highest reactivity among the four kinds of oxygen carriers. In a later study, the same research group investigated the feasibility of the use of an Mn-based oxygen carrier supported on zirconia stabilized with magnesium in a $300 \mathrm{~W}$ continuously operating reactor system [68]. As a result, $\mathrm{Mn}_{3} \mathrm{O}_{4} / \mathrm{Mg}-\mathrm{ZrO}_{2}$ particles sintered at $1150^{\circ} \mathrm{C}$ showed a good reactivity for CLC. Very high efficiencies of $>0.999$ were obtained for syngas combustion at all temperatures in the range of $800-950^{\circ} \mathrm{C}$. Agglomeration and attrition rate were not obviously observed. The same authors investigated the reduction and oxidation kinetics of $\mathrm{Mn}_{3} \mathrm{O}_{4} / \mathrm{Mg}-\mathrm{ZrO}_{2}$ oxygen carrier particles for CLC in a subsequent work [69]. The order of reaction was 1 with respect to $\mathrm{CH}_{4}$ and 0.65 with respect to $\mathrm{O}_{2}$. The activation energy for the reduction and oxidation reactions were 119 and $19 \mathrm{~kJ} / \mathrm{mol}$, respectively. The oxygen carrier particles showed high reactivity during both reduction and oxidation at all investigated temperatures of $800-950^{\circ} \mathrm{C}$. The oxygen carrier was reduced to $\mathrm{MnO}$ in the course of reduction and oxidized to $\mathrm{Mn}_{3} \mathrm{O}_{4}$ during oxidation at all conditions. It is clear that $\mathrm{ZrO}_{2}$ stabilized by $\mathrm{MgO}$ is a good support and inert binder for Mn-based oxygen carriers.

2.5. Other Oxygen Carriers. Beside the aforementioned oxygen carriers, other kinds of materials have been reported being used as oxygen carriers for CLC, such as perovskite, $\mathrm{CaSO}_{4}$, as well as mixed-metal oxides. Actually, perovskites are mixed oxides with the general formula $\mathrm{ABO}_{(3+\delta)}$, where A is usually a ion of a rare earth metal, an alkali metal, or an alkaline earth metal B is a transition metal ion. Both A and $\mathrm{B}$ can be partially substituted, leading to a wide variety of compositions of general formula $\mathrm{A}_{1-\mathrm{x}} \mathrm{A}_{\mathrm{x}}^{\prime} \mathrm{B}_{1-\mathrm{y}} \mathrm{B}_{\mathrm{y}}^{\prime} \mathrm{O}_{(3+\delta)}$, characterized by structural and electronic defects owing to their nonstoichiometry [70]. The $\delta$-factor in perovskites can be reduced or increased by changing factors in the conditions such as temperature or $\mathrm{O}_{2}$ partial pressure. This characterization makes perovskites potentially to be used as oxygen carriers for CLC. Readman et al. [71] studied the feasibility of $\mathrm{La}_{0.8} \mathrm{Sr}_{0.2} \mathrm{Co}_{0.2} \mathrm{Fe}_{0.8} \mathrm{O}_{3-\delta}$ as a potential oxygen carrier in a chemical-looping reactor. The results suggested that $\mathrm{La}_{0.8} \mathrm{Sr}_{0.2} \mathrm{Co}_{0.2} \mathrm{Fe}_{0.8} \mathrm{O}_{3-\delta}$ has the redox properties required for chemical looping. Reduction and reoxidation of the perovskite takes place quickly enough for CLC. However, it displayed a low oxygen carrying capacity. Rydén et al. [72] reported the use of $\mathrm{La}_{x} \mathrm{Sr}_{1-x} \mathrm{Fe}_{y} \mathrm{Co}_{1-y} \mathrm{O}_{3-\delta}$ as oxygen carriers for CLC or chemical-looping reforming (CLR). They found that $\mathrm{La}_{0.5} \mathrm{Sr}_{0.5} \mathrm{Fe}_{0.5} \mathrm{Co}_{0.5} \mathrm{O}_{3-\delta}$ has properties that make high conversion of $\mathrm{CH}_{4}$ into $\mathrm{H}_{2} \mathrm{O}$ and $\mathrm{CO}_{2}$ in the beginning of each reduction period. Substituting $\mathrm{La}$ for $\mathrm{Sr}$ could increase the oxygen carrying capacity of the perovskite, but reduced the reactivity with $\mathrm{CH}_{4}$.

The oxygen carriers of individual metal oxides have their own advantages and drawbacks. For example, Nibased oxygen carriers allow working at high temperature in CLC with high $\mathrm{CH}_{4}$ conversion, but the drawbacks are the higher carbon formation rate as well as partial oxidation of $\mathrm{CH}_{4}$ to $\mathrm{CO}$ and $\mathrm{H}_{2}$. On the other hand, $\mathrm{Cu}$-based oxygen carriers give complete fuel combustion to $\mathrm{CO}_{2}$ and $\mathrm{H}_{2} \mathrm{O}$, but the operating temperature is lower because of the low melting point of the $\mathrm{Cu}$. Mixed-metal oxides may integrate the advantages of each sole oxides as well as partially avoid their disadvantages. Jin et al. in [14] reported that double metal oxides of $\mathrm{CoO}-\mathrm{NiO} / \mathrm{YSZ}$ provided a better performance with good reactivity, complete avoidance of carbon deposition, and significant regenerability for repeated cycles of reduction and oxidation than those of individual metal oxides of $\mathrm{NiO} / \mathrm{YSZ}$ and $\mathrm{CoO} / \mathrm{YSZ}$. Adánez et al. [73] prepared mixed $\mathrm{Ni}-\mathrm{Cu}$ oxides and examined their performance for CLC of methane. It was revealed that the presence of $\mathrm{CuO}$ in the $\mathrm{Ni}-\mathrm{Cu}$ oxygen carriers gives the full conversion of $\mathrm{CH}_{4}$ to $\mathrm{CO}_{2}$ and $\mathrm{H}_{2} \mathrm{O}$ with zero $\mathrm{CO}$ and $\mathrm{H}_{2}$ emissions. Additionally, the presence of $\mathrm{NiO}$ in the $\mathrm{Ni}-\mathrm{Cu}$ oxygen carriers allows the particles operating at high temperature $\left(950^{\circ} \mathrm{C}\right)$. Hossain and de Lasa [74] developed a bimetallic $\mathrm{Co}-\mathrm{Ni} / \mathrm{Al}_{2} \mathrm{O}_{3}$ oxygen carrier for a fluidized bed chemical-looping combustion process. The Co$\mathrm{Ni} / \mathrm{Al}_{2} \mathrm{O}_{3}$ particles displayed excellent reactivity and stability. They confirmed that the addition of Co in the double metallic $\mathrm{Co}-\mathrm{Ni} / \mathrm{Al}_{2} \mathrm{O}_{3}$ particles influences the state of the surface minimizing the formation of nickel aluminate, which was believed to be contributing to the inferior reactivity of Ni-based oxygen carriers. Besides, the addition of Co inhibits metal particle agglomeration during the cyclic redox processes. The activation energy for $\mathrm{Co}-\mathrm{Ni} / \mathrm{Al}_{2} \mathrm{O}_{3}$ reduction was found to be less than that of unpromoted $\mathrm{Ni} / \mathrm{Al}_{2} \mathrm{O}_{3}$ samples. This suggested that doping with Co decreases the metal-support interaction and the binding energies between the metals and the fuel molecules [53]. Johansson et al. [75] investigated the synergy effect by using mixed oxides of iron and nickel in combustion of $\mathrm{CH}_{4}$ in a CLC reactor. It was shown that the mixed-oxide system of $3 \%$ nickel oxides in $97 \%$ iron oxides gives almost two times as much $\mathrm{CO}_{2}$ per time unit in comparison to the sum of $\mathrm{CO}_{2}$ when the oxides were tested separately. They believed that the presence of metallic Ni could firstly catalyze the methane into $\mathrm{CO}$ and $\mathrm{H}_{2}$, which then reacts with iron oxide at a considerably higher rate than methane.

Recently, $\mathrm{CaSO}_{4}$ was considered as oxygen carrier in CLC. Song et al. [76] studied the CLC of methane with $\mathrm{CaSO}_{4}$ oxygen carrier in a fixed bed reactor. The results showed that the $\mathrm{CaSO}_{4}$ oxygen carrier has a good reduction reactivity and stability in a long-term redox test at $950^{\circ} \mathrm{C}$. The $\mathrm{CH}_{4}$ conversion rate was found as a function of temperature, gas flow rate, mass of sample loaded, and particle size of oxygen carrier. High temperatures lead to a high $\mathrm{CH}_{4}$ conversion into $\mathrm{CO}_{2}$, however, a significant 
$\mathrm{SO}_{2}$ formation was observed at higher temperatures. In a later work, the same researchers investigated the cyclic performance of a $\mathrm{CaSO}_{4}$-based oxygen carrier in alternating reducing simulated coal gas and oxidizing conditions [77]. It was found that a high concentration of $\mathrm{CO}_{2}$ could be obtained in the reduction. The coal gas conversions and $\mathrm{CO}_{2}$ yield initially increased and finally decreased during the reduction in the multicycle tests. Similar to their previous work, the formation of $\mathrm{SO}_{2}$ and $\mathrm{H}_{2} \mathrm{~S}$ during the cyclic tests was found to be responsible for the decay of the reactivity of the $\mathrm{CaSO}_{4}$ oxygen carrier. Therefore, decomposition at hightemperature condition is a major problem for $\mathrm{CaSO}_{4}$ when it is used as oxygen carrier for CLC. Decomposition behaviors of $\mathrm{CaSO}_{4}$ in chemical-looping combustion were studied by Tian et al. [78]. They claimed that the most likely mechanism function in the decomposition of $\mathrm{CaSO}_{4}$ is characterized by the Avrami-Erofeev equation. The decomposition reaction is dominated by the nucleation rate. The work in [76] represented that the release of $\mathrm{SO}_{2}$ and $\mathrm{H}_{2} \mathrm{~S}$ can be avoided by optimization of the operating conditions. Addition of a minor amount of fresh limestone into the system of CLC can capture the $\mathrm{SO}_{2}$, and the products of $\mathrm{CaSO}_{4}$ and $\mathrm{CaS}$ can be used as oxygen carriers later [79].

\section{CLC Reactor Design}

Prior to the year 2001, most of the research work on CLC focused on the development of oxygen carriers and on system studies, with limited information about how the CLC reactors could be designed [80]. In CLC process it is required a good contact between fuels and oxygen carriers as well as a flow of solid material between the two reactors. Although there are several options for CLC system designs, it is likely that interconnected fluidized bed reactors are believed the most suitable reactor design. Lyngfelt et al. [4] proposed a circulating system composed of two interconnected fluidized beds, that is, a high-velocity riser and a low-velocity bubbling fluidized bed, see Figure 3. The bed material (oxygen carrier particles) was circulated between the two fluidized beds. In the air reactor (the riser), oxygen is transferred from the combustion air to the oxygen carrier. In the fuel reactor (the low-velocity fluidized bed), oxygen is transferred from the oxygen carrier to the fuel. The authors presented the critical design parameters, such as the solids inventory, recirculation rate of the oxygen carriers, the dimensions of the reactors, as well as the pressure drops. The same authors constructed a $10 \mathrm{~kW}$ chemical looping combustor and operated for 100 hours using $\mathrm{NiO}$-based oxygen carriers and natural gas as fuel in 2005 [81]. However, $99.5 \%$ of the added methane was converted into $\mathrm{CO}_{2}$ and $\mathrm{H}_{2} \mathrm{O}$, with minor of $\mathrm{CO}, \mathrm{H}_{2}$, and unreacted methane in the exit stream. There was no detectable leakage between the two reactors. And $\mathrm{CO}_{2}$ escape from the system via the air reactor was not found. Therefore, almost $100 \%$ of the $\mathrm{CO}_{2}$ is captured in the process.

Kronberger et al. [82] designed a $10 \mathrm{~kW}$ CLC prototype of a dual-fluidized bed reactor system. Gas velocities and designs were varied, while solids circulation rate and gas leakage between the reactor as well as static pressure balance and residence time distribution of gas and particles were

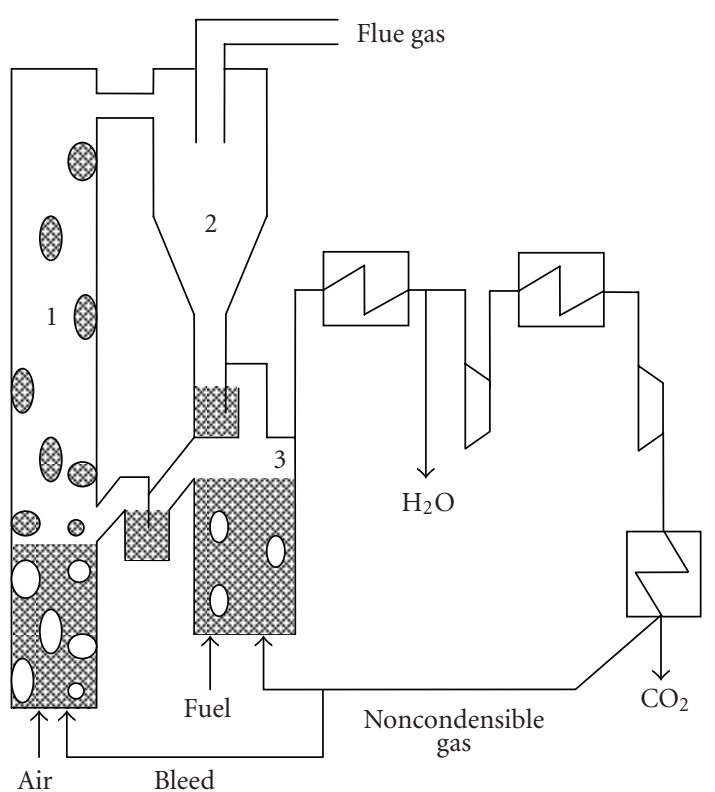

FIGURE 3: Layout of chemical-looping combustion process, with two interconnected fluidized beds. (1) air reactor, (2) cyclone, (3) fuel reactor.

measured. It was observed that the solid circulation rates were sufficient and the gas leakage could be controlled at very low level. In one of their previous work, the same authors developed a $300 \mathrm{~W}$ fluidized-bed reactor for CLC [83]. The reactor was tested in various gas velocities and slot design. CLC in the same reactor was continuously operated using Mn-based oxygen carrier [68].

Linderholm et al. [26] examined the CLC process for 160 hours in a $10 \mathrm{~kW}$ reactor system with an $\mathrm{NiO} / \mathrm{NiAl}_{2} \mathrm{O}_{4}$ oxygen carrier and natural gas as fuel. The prototype consisted of two interconnected fluidized-bed reactors, the fuel and the air reactors, a cyclone to separate solid from gas flow out of the air reactor, and two loop seals, see Figure 4. High fuel conversion to $\mathrm{CO}_{2}$ and $\mathrm{H}_{2} \mathrm{O}$ was achieved. The outlet gas stream out of the fuel reactor mainly contained $\mathrm{CO}_{2}$ with approximately $0.7 \% \mathrm{CO}, 0.3 \% \mathrm{CH}_{4}$, and $1.3 \%$ $\mathrm{H}_{2}$. The estimated particle life time was 4500 hours. A concentrated stream of $\mathrm{CO}_{2}$ was obtained when steam was used as fluidization gas in particle locks. Adánez et al. [47] has designed and built a $10 \mathrm{~kW}$ pilot plant that is composed of two interconnected bubbling fluidized-bed reactors to demonstrate the CLC technology, see Figure 5. The system was operated for 200 hours, 120 hours of which involved the burning of methane using $\mathrm{CuO} / \mathrm{Al}_{2} \mathrm{O}_{3}$ oxygen carrier. Complete methane conversion was achieved and no deactivation of the oxygen carrier was noticed at $800^{\circ} \mathrm{C}$. Similar results were obtained by the same authors [41].

Son and Kim [34] built an annular shape circulating fluidized-bed (CFB) reactor with double loops for investigation into CLC. They tested the CLC of $\mathrm{CH}_{4}$ using mixed $\mathrm{NiO}-\mathrm{Fe}_{2} \mathrm{O}_{3}$ particles supported on bentonite at $850^{\circ} \mathrm{C}$. Full conversion of $\mathrm{CH}_{4}$ to $\mathrm{CO}_{2}$ and $\mathrm{H}_{2} \mathrm{O}$ was achieved with very small amount of $\mathrm{CO}$ and no $\mathrm{H}_{2}$ emission was detected. Recently, a number of researchers started to investigate the 


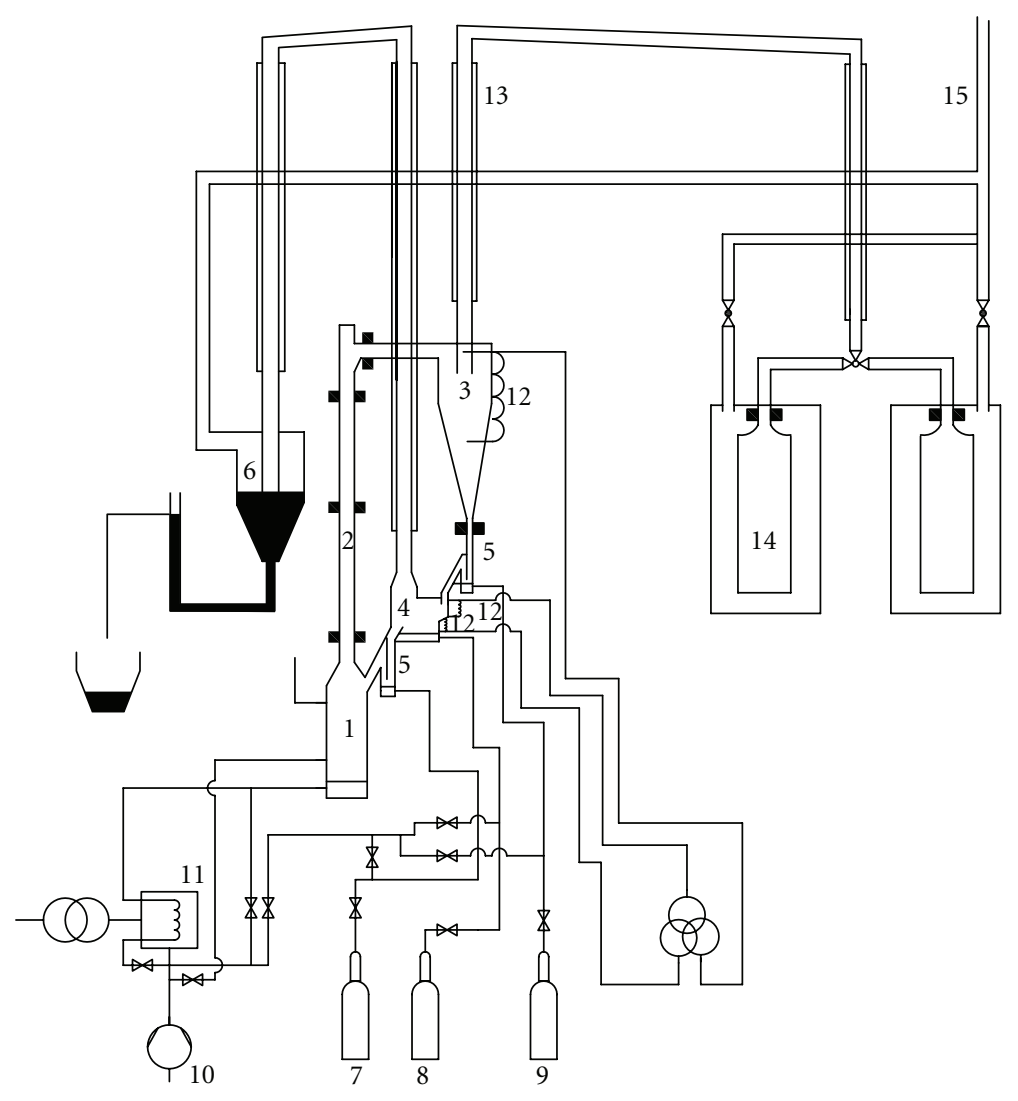

FIGURE 4: Schematic diagram of the prototype reactor system. (1) air ractor, (2) riser, (3) cyclone, (4) fuel reactor, (5) upper and lower particle locks, (6) water trap, (7) nitrogen (8) natural gas, (9) argon, (10) air, (11) preheater, (12) heating coils (not available for test with nickel-based particles), (13) finned tubes for cooling of gas streams, (14) filters, and (15) connection to chimney.

feasibility of CLC for solid fuel. Berguerand and Lyngfelt [84] designed a $10 \mathrm{~kW}$ chemical-looping combustor for solid fuels, and tested with South African coal. The CLC system for solid fuels is very similar to the ones for gas fuels, which was reported in literature [22, 26] (see Figure 4). To adapt the solid fuels important modifications in the fuel reactor chamber and the inclusion of an additional solids recirculation loop were made. Additionally, steam was used as the fluidizing agent instead of the fuel gas flow. The chemical-looping combustor has been operated with South African coal for 22 hours, with approximately 12 hours of stable CLC conditions. Ilmenite was proved to be a suitable oxygen carrier for the tested solid fuel with good mechanical properties, low fragmentation/attrition, and good reactivity. The $\mathrm{CO}_{2}$ capture varied between $82.5 \%$ and $96.0 \%$ for the coal tests.

Recently, a couple of CLC pilot plants at fuel power of $10-140 \mathrm{~kW}$ were built and tested with different fuels. Kolbitsch et al. $[85,86]$ built a $120 \mathrm{~kW}$ CLC pilot unit with dual circulating fluidized bed (DCFB) reactor system, and successfully put it into operation. Two different oxygen carriers, that is, ilmenite and a designed Ni-based particle, were tested in the CLC unit. The experimental results with ilmenite and $\mathrm{H}_{2}$ rich gases as fuel showed very promising results. High gas conversion was observed. The Ni-based oxygen carrier achieved thermodynamic maximum $\mathrm{H}_{2}$ and $\mathrm{CO}$ conversion as well as very high $\mathrm{CH}_{4}$ conversion when the solids inventory is sufficiently high. The same research group compared the performance of two Ni-based oxygen carriers, that is, $\mathrm{NiO} / \mathrm{NiAl}_{2} \mathrm{O}_{4}$ and $\mathrm{NiO} / \mathrm{NiMgAl}_{2} \mathrm{O}_{4}$, for chemical looping combustion of natural gas in the same CLC pilot rig on a scale of $140 \mathrm{~kW}$ fuel power [87]. Both oxygen carriers showed high reactivity and no carbon formation was observed under any conditions. Linderholm et al. [88] investigated the reactivity and physical characteristics of Ni-based particles in a $10 \mathrm{~kW}$ chemical looping combustor composed of two interconnected fluidized-bed reactors with natural gas as fuel. Long-term of fuel operation (>1000 hours) were achieved. The combustion efficiency was around $98 \%$ and the methane fraction was typically $0.4-1 \%$ in the flue gas of fuel reactor. The particle lifetime was estimated up to 33000 hours based on calculation from the loss of fines. Shen et al. [89] carried out the experiments for CLC of biomass with iron oxide as an oxygen carrier in a $10 \mathrm{~kW}$ continuous reactor of interconnected fluidized beds. The results showed that an increase in the fuel reactor temperature produced a higher increase for the $\mathrm{CO}$ production from biomass gasification than for the consumption of $\mathrm{CO}$ oxidation to $\mathrm{CO}_{2}$. The transformation of $\mathrm{Fe}_{2} \mathrm{O}_{3}$ to $\mathrm{Fe}_{3} \mathrm{O}_{4}$ is the favored step in the process of iron oxide reduction with biomass 


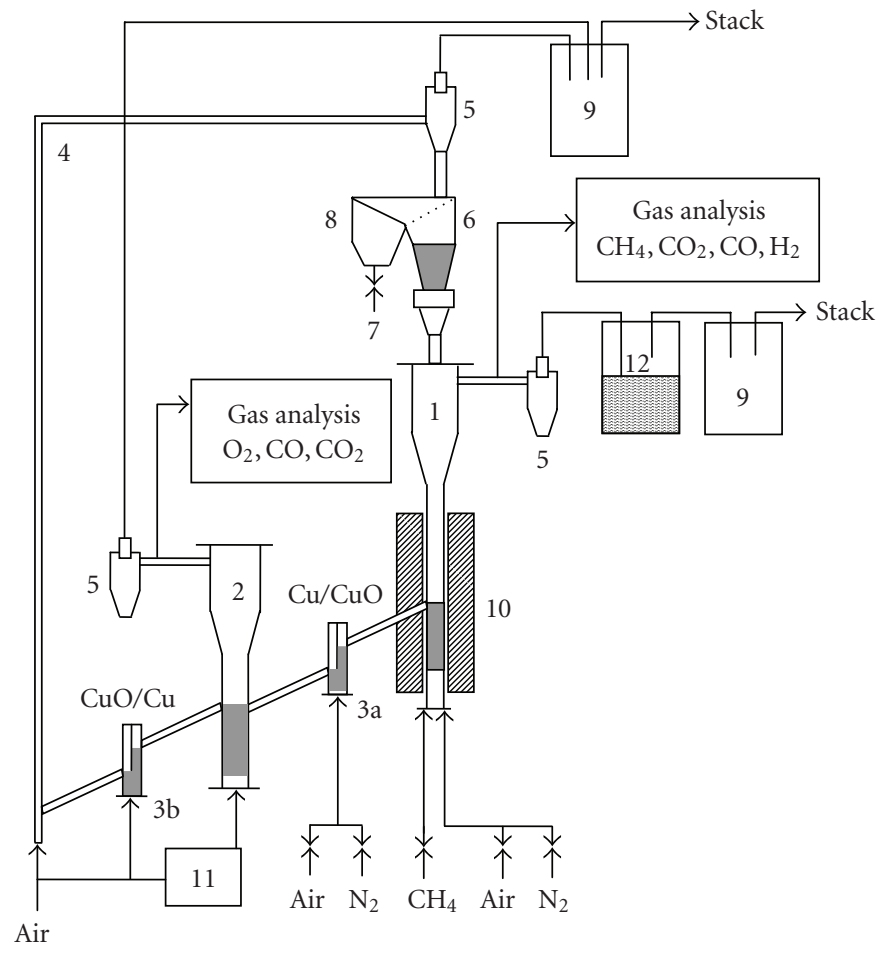

FIGURE 5: Schematic diagram of the CLC facility of instituto de carboquimica (C.S.I.C.), Spain. (1) fuel reactor, (2) air reactor, (3) loop seals, (4) riser, (5) cyclone, (6) solid reservoir, (7) solids valve, (8) diverting solid valve, (9) filters, (10) oven, (11) air preheater, and (12) water condenser.

syngas. Ryu and Jin [90] proposed a conceptual design a $50 \mathrm{~kW}$ thermal chemical-looping combustor composed of two interconnected pressurized circulating fluidized beds. They calculated the important parameters such as bed mass, solid circulation flux, and reactor dimension.

\section{Chemical-Looping Reforming (CLR) and Chemical-Looping Hydrogen (CLH)}

The chemical-looping technique can also be employed for methane reforming and production of hydrogen with inherent $\mathrm{CO}_{2}$ capture. Chemical-looping reforming (CLR) uses the same basic principles as CLC, with the main difference that the target products in CLR are $\mathrm{H}_{2}$ and $\mathrm{CO}$ instead of heat. The basic principles of chemical-looping reforming are illustrated in Figure 6 [91].

In the fuel reactor of CLR process, the fuels are partially oxidized using a solid oxygen carrier to produce synthesis gas, a mix of $\mathrm{H}_{2}$ and $\mathrm{CO}$, instead of being oxidized into $\mathrm{CO}_{2}$ and $\mathrm{H}_{2} \mathrm{O}$. Therefore, the ratio of oxygen to fuel is kept low to prevent the fuel from becoming fully oxidized. Pure oxygen production plant which is needed in normal natural gas reforming is avoided. Rydén et al. [91] investigated the CLR of natural gas in a circulating fluidized-bed reactor using $\mathrm{Ni}$ based oxygen carriers. It was found that CLR is a feasible concept for production of synthesis gas and hydrogen. The conversion of natural gas into synthesis gas was $96 \%-100 \%$ depending on oxygen carrier and experimental conditions. The same authors [31] evaluated the feasibility of synthesis

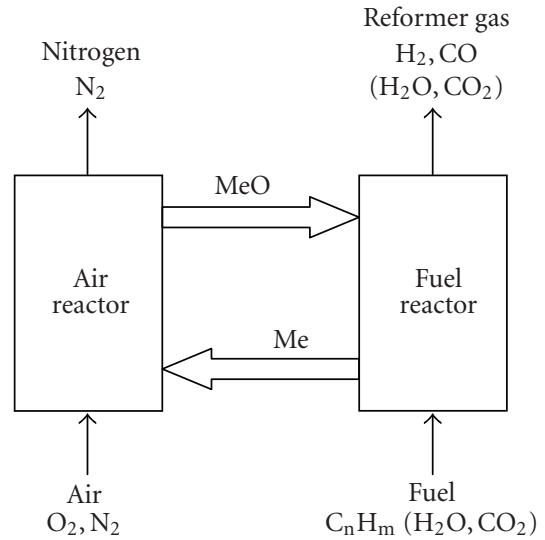

FIgURE 6: Schematic description of chemical-looping reforming.

gas generation by CLR of natural gas in a continuously operating laboratory reactor using a Ni-based oxygen carrier. As a result, complete conversion of natural gas was achieved and the selectivity towards $\mathrm{H}_{2}$ and $\mathrm{CO}$ was high. Carbon deposition was found for some cases, which was eliminated by adding $25 \mathrm{vol} \%$ steam to the natural gas. de Diego et al. [92] studied the synthesis gas generation by chemicallooping reforming of methane using a Ni-based oxygen carrier in a $900 \mathrm{~W}_{\text {th }}$ CLR pilot plant. The effect of operating conditions, such as fuel reactor temperature, $\mathrm{H}_{2} \mathrm{O} / \mathrm{CH}_{4}$ molar ratio, and solid circulation, on $\mathrm{CH}_{4}$ conversion and gas product distribution was analyzed. The $\mathrm{CH}_{4}$ conversion rate 
reached $>98 \%$ in all operating conditions. When $\mathrm{NiO} / \mathrm{CH}_{4}$ molar ratio was 1.25 , a dry gas product composition of 65 vol $\% \mathrm{H}_{2}, 25$ vol $\% \mathrm{CO}, 9$ vol $\% \mathrm{CO}_{2}$, and $1-1.5$ vol $\% \mathrm{CH}_{4}$ was obtained in the CLR process. Also, de Diego et al. [93] studied the CLR of $\mathrm{CH}_{4}$ in a thermogravimetric analyzer (TGA) and in a batch fluidized bed reactor using Ni-based oxygen carriers. The support used to prepare the oxygen carriers exhibited an important effect on the reactivity of the oxygen carriers, on the gas product distribution, and on the carbon deposition. The Ni-based oxygen carrier impregnated on $\alpha-\mathrm{Al}_{2} \mathrm{O}_{3}$ showed the highest reactivity during the reduction reaction. For all of the tested oxygen carriers, the reduction time without carbon deposition increased with increasing the reduction reaction temperature and the $\mathrm{H}_{2} \mathrm{O} / \mathrm{CH}_{4}$ molar ratio in the feed. The $\mathrm{H}_{2} / \mathrm{CO}$ molar ratio in the gas product generated during $\mathrm{CH}_{4}$ reforming was between 2 and 3 in the reduction period. In a later article, the same researchers presented the experimental results of autothermal CLR of methane in a $900 \mathrm{~W}_{\text {th }}$ circulating fluidized bed reactor under continuous operation using Nibased oxygen carriers [94]. It was observed that the $\mathrm{CH}_{4}$ conversion was very high $(>98 \%)$ in all operating conditions with both oxygen carriers of $21 \mathrm{wt} \% \mathrm{NiO}$ supported on $\gamma$ $\mathrm{Al}_{2} \mathrm{O}_{3}$ and $18 \mathrm{wt} \% \mathrm{NiO}$ on $\alpha-\mathrm{Al}_{2} \mathrm{O}_{3}$. The oxygen carrier circulation rate, that is, the $\mathrm{NiO} / \mathrm{CH}_{4}$ molar ratio was the most important factor affecting the gas product distribution. Synthesis gas of $\mathrm{H}_{2} / \mathrm{CO}$ ratio near 2.6/1 with minor amount of $\mathrm{CO}_{2}$ and unreacted $\mathrm{CH}_{4}$ was obtained. Significant changes in the reactivity, surface texture, and solid structure of the oxygen carrier particles were not observed after 50 hours of operation. From these previous literatures, it can be seen clearly that reforming of methane or natural gas by chemicallooping technique is feasible.

Recently, chemical-looping process was proposed being used to produce hydrogen. Chemical-looping hydrogen (CLH) generation, which originates from CLC, actually is a type of water splitting process with a redox of a metal oxide. Similarly to CLC, the CLH system is composed of two reactors: a fuel reactor for burning fuels, and a steam reactor for water decomposition, which is different from the air reactor in the CLC. Fuel is introduced into the fuel reactor to reduce the metal oxide particles, meanwhile the fuel is oxidized into $\mathrm{CO}_{2}$ and $\mathrm{H}_{2} \mathrm{O}$. The reduced metal oxide is transported to the steam reactor, where it decomposes water to generate $\mathrm{H}_{2}$. The outlet gas stream from the fuel reactor contains only $\mathrm{CO}_{2}$ and $\mathrm{H}_{2} \mathrm{O}$ at complete conversion of the fuel, while the exit gas from the steam reactor is just $\mathrm{H}_{2}$ with excess $\mathrm{H}_{2} \mathrm{O}$. Therefore, pure $\mathrm{H}_{2}$ and $\mathrm{CO}_{2}$ can be obtained with $\mathrm{H}_{2} \mathrm{O}$ condensation without any further separation process [95]. The work in [95] reported that $3.7 \mathrm{~L}$ of $\mathrm{H}_{2}$ was generated through reaction between per kilogram fully reduced copper-based oxide and steam. Go et al. [96] investigated hydrogen production by chemical-looping of methane in a fluidized-bed reactor using iron-based oxygen carrier. It was found that pure hydrogen with free- $\mathrm{CO}_{2}$ can be obtained from the reaction of $\mathrm{FeO} \rightarrow \mathrm{Fe}_{3} \mathrm{O}_{4}$ in steam reactor at $900^{\circ} \mathrm{C}$. Additionally, the authors proposed the design basis for the continuous two step steam-methanereforming (SMR) with double-loop solids circulation system

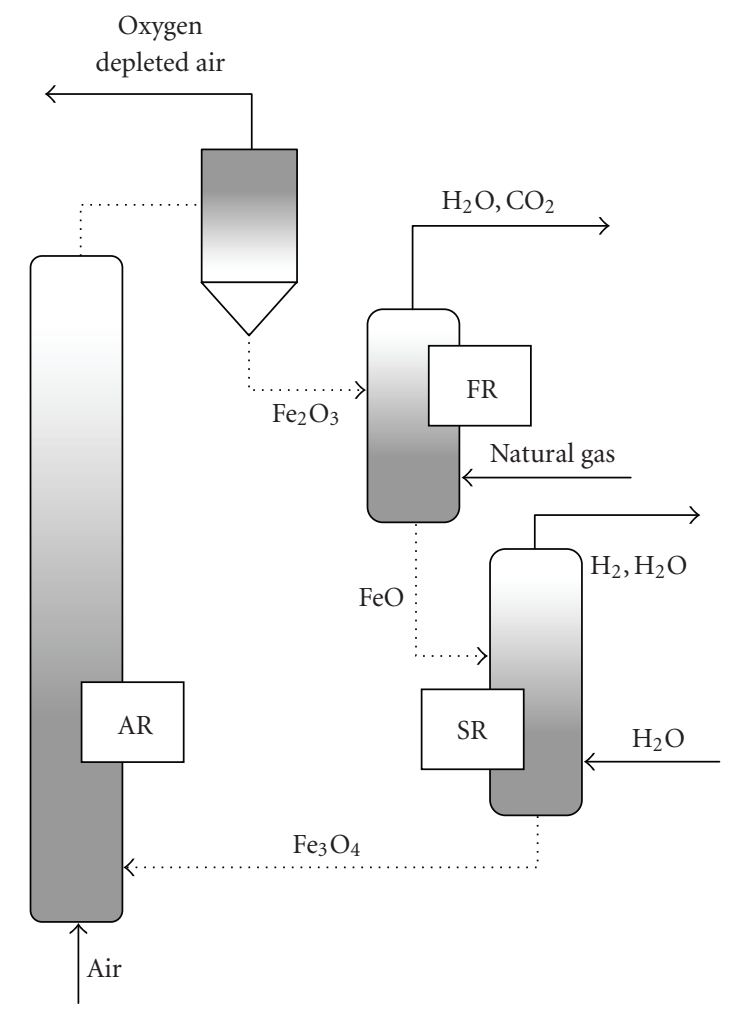

FIGURE 7: Conceptual scheme of the three-reactor CLH system. AR: air reactor; FR: fuel reactor, SR: steam reactor.

for fuel and steam. Solid fuels, such as coal char, were reported being used as reducing materials in CLR. Yang et al. [97] investigated $\mathrm{H}_{2}$ production from steam-iron process with reduction of iron oxide by CLC of coal char. Iron oxide was used to oxidize the coal char into $\mathrm{CO}_{2}$ and $\mathrm{H}_{2} \mathrm{O}$ leading to the reduction of $\mathrm{Fe}_{2} \mathrm{O}_{3}$ to $\mathrm{FeO}$ and metallic $\mathrm{Fe}$ in the fuel reactor. The reduced iron oxide, $\mathrm{FeO}$ and $\mathrm{Fe}$, was oxidized by steam in the steam reactor, while $\mathrm{H}_{2}$ was generated by water decomposing. Usually, $\mathrm{FeO}$ and $\mathrm{Fe}$ are oxidized to $\mathrm{Fe}_{3} \mathrm{O}_{4}$ in the steam reactor. Therefore, an air reactor is needed, where the $\mathrm{Fe}_{3} \mathrm{O}_{4}$ is oxidized to the original $\mathrm{Fe}_{2} \mathrm{O}_{3}$ by air. The authors proved that $\mathrm{FeO}$ and $\mathrm{Fe}$ produced from the $\mathrm{Fe}_{2} \mathrm{O}_{3}$ reduction of char were feasible for $\mathrm{H}_{2}$ production through the steamiron process. The total $\mathrm{H}_{2}$ produced was $1000 \mathrm{~mL}$ of $\mathrm{H}_{2}$ per gram of tested coal char, where the energy efficiency was $50.2 \%$ with respect to the energy ratio of $\mathrm{H}_{2} /$ char.

Similarly, Chiesa et al. [98] proposed a CLH production system with three reactors. The conceptual scheme of the three reactor of CLH is shown in Figure 7. Compared to commercially available technologies, this $\mathrm{CLH}$ process shows similar efficiency but much better environmental benign because of the inherent $\mathrm{CO}_{2}$ separation. They concluded that the CLH system is a promising hydrogen production process deserving substantial research and development activities in the near future. In the steam-iron process to produce hydrogen, deactivation of the iron oxide is one of the problems during the operation. Bleeker et al. [99] considered that the deactivation of the iron oxide is caused by a decrease in the surface area of the oxygen carrier particles. Further, a 


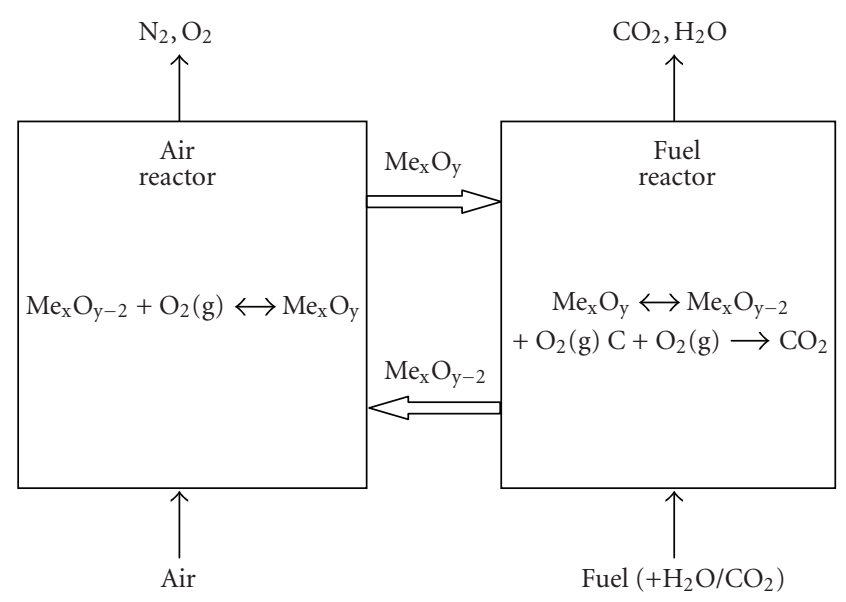

FIgure 8: Principal layout of chemical-looping oxygen uncoupling. The oxygen carrier is denoted by $\mathrm{Me}_{\mathrm{x}} \mathrm{O}_{\mathrm{y}}$ and $\mathrm{Me}_{\mathrm{x}} \mathrm{O}_{\mathrm{y}-2}$, where $\mathrm{Me}_{\mathrm{x}} \mathrm{O}_{\mathrm{y}}$ is a metal oxide and $\mathrm{Me}_{\mathrm{x}} \mathrm{O}_{\mathrm{y}-2}$ is a metal or metal oxide with lower oxygen content. Here, the fuel is carbon. The fuel reactor could be fluidized using recirculated $\mathrm{CO}_{2}$ or steam when burning solid fuel [101].

higher conversion degree of the oxygen carriers in the redox cycles will give a stronger deactivation.

\section{Chemical-Looping with Oxygen Uncoupling (CLOU)}

When CLC process is used to burn solid fuel, there are two approaches operating the combustor to adapt the solid fuels. One option is to introduce the solid fuels directly to the fuel reactor where the gasification of the solid fuels and subsequent reactions with the oxygen carriers will occur simultaneously. Another strategy is to use an oxygen carrier which releases $\mathrm{O}_{2}$ in the fuel reactor firstly and thereby allowing the fuel to burn with gas-phase oxygen [100]. As for the first method, there is usually a need for an intermediate gasification step of the solid fuels with steam or carbon dioxide to form reactive gaseous compounds which then react with the oxygen carrier particles. Generally, the gasification of solid fuels with $\mathrm{H}_{2} \mathrm{O}$ and $\mathrm{CO}_{2}$ is inherently slow leading to slow overall reaction rates. The second option is referred to as chemical-looping with oxygen uncoupling (CLOU). In the CLOU combustion, the slow gasification of solid fuels with $\mathrm{H}_{2} \mathrm{O}$ and $\mathrm{CO}_{2}$ is avoided, since the fuels reacts directly with gas-phase oxygen. The combustion technique of CLOU involves three steps in two reactors, see Figure 8.

Mattisson et al. [102] presented the chemical-looping with oxygen uncoupling for combustion of petroleum coke. Thermodynamic analysis showed that $\mathrm{Mn}_{2} \mathrm{O}_{3} / \mathrm{Mn}_{3} \mathrm{O}_{4}$ and $\mathrm{CuO} / \mathrm{Cu}_{2} \mathrm{O}$ are the most two promising candidates of oxygen carrier for CLOU combustion of solid fuels. The CLOU combustion of petroleum coke was tested in a batch laboratory fluidized-bed reactor and compared to the results of normal CLC. It was found that the reaction rate of petroleum coke was 50 times higher using CLOU than the reaction rate of the same fuel with a $\mathrm{Fe}_{2} \mathrm{O}_{3}$-based oxygen carrier in normal CLC. In a later work, the same authors [101] studied the CLOU using $\mathrm{CuO} / \mathrm{ZrO}_{2}$ as oxygen carrier and petroleum coke as fuel in a laboratory fluidized bed reactor of quartz. The temperature gave an obvious effect on the reaction rate of petroleum coke. Conversion rates varied between $0.5 \% / \mathrm{s}$ and $5 \% / \mathrm{s}$ at a set-point temperature from $895^{\circ} \mathrm{C}$ to $985^{\circ} \mathrm{C}$. These reaction rates are significantly higher than the rates with the same fuel in regular CLC. Therefore, the CLOU is a promising alternative for combustion of solid fuels inherently $\mathrm{CO}_{2}$ capture.

\section{Carbon Formation}

Carbon formation may occur during reduction period if carbon-containing fuels are used in CLC. The carbon formation is believed taking place as two mechanisms: pyrolysis of methane and Boudouard reaction (see (3)):

$$
\begin{gathered}
\mathrm{CH}_{4} \longrightarrow \mathrm{C}+2 \mathrm{H}_{2} \quad \text { (pyrolysis) }, \\
2 \mathrm{CO} \longrightarrow \mathrm{C}+\mathrm{CO}_{2} \quad \text { (Boudouard reaction). }
\end{gathered}
$$

The pyolysis of methane is thermodynamically favored at high temperature as an endothermic reaction. The Boudouard reaction is exothermic more likely to occur at lower temperatures. Chandel et al. [103] suggested that both of the pyrolysis and Boudouard reactions are slow in CLC process without a catalyst. However, transition metals such as $\mathrm{Ni}$ and $\mathrm{Fe}$ can act as a catalyst for methane decomposition. Especially, metallic nickel is well known a good catalyst for thermal decomposition of hydrocarbons. This side reaction is undesirable in a CLC process since it increases methane consumption in clear competition with the main reaction in the reduction period. The formed carbon will be burned into $\mathrm{CO}_{2}$ in oxidation stage resulting in lower efficiency of $\mathrm{CO}_{2}$ capture of the whole CLC process. Carbon formation using nickel-based oxygen carriers can be decreased by using mixed oxides as oxygen carriers or adding steam into the fuel gas [48]. Other conditions such as oxygen availability of oxygen carriers, fuel conversion, temperature, and pressure could affect the carbon formation. Generally, carbon is prone to be formed at low temperature and small amounts of added oxygen. Here, the oxygen added ratio, $\varsigma$, is defined as the actual amount of $\mathrm{O}$, added with the oxide and/or with steam, over the stoichiometric amount needed for full conversion of the fuel [104]:

$$
\varsigma=\frac{n_{\text {O,added }}}{n_{\text {O,stoich }}} .
$$

Carbon deposition is thermodynamically favorable at a lower oxygen added ratio. Figure 9 shows the carbon formation as a function of temperature and oxygen-added ratio at various pressure independent on the oxygen carrier used when $\mathrm{CH}_{4}$ is used as fuel in CLC. It is clear that an increased pressure will enhance carbon formation at low temperature, while an increased pressure will reduce carbon formation at high temperature. This is due to the fact that less carbon is formed at higher pressures through methane pyrolysis while more carbon is formed at higher pressures by the Boudouard reaction. 


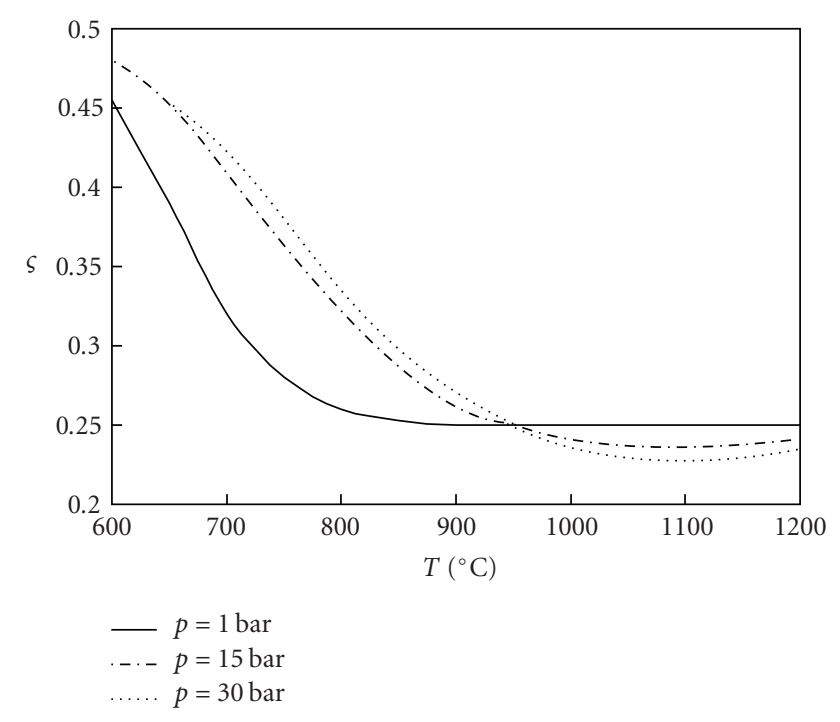

Figure 9: The oxygen added ratio, $\varsigma$, needed to avoid carbon formation when $\mathrm{CH}_{4}$ is used as fuel [104].

Addition of water vapor into the fuels before being introduced to the fuel reactor would obviously inhibit the carbon deposition for $\mathrm{NiO} / \mathrm{NiAl}_{2} \mathrm{O}_{4}$ particle [13]. The decrease in carbon formation with the addition of steam to methane may be explained with steam reforming and the shift reaction as follows:

$$
\begin{gathered}
\mathrm{CH}_{4}+\mathrm{H}_{2} \mathrm{O} \longrightarrow \mathrm{CO}+3 \mathrm{H}_{2} \quad \text { (Steam reforming), } \\
\mathrm{CO}+\mathrm{H}_{2} \mathrm{O} \longrightarrow \mathrm{CO}_{2}+\mathrm{H}_{2} \quad \text { (Shift reaction). }
\end{gathered}
$$

Apart from above two reactions, carbon formation may be reduced by another reaction as (6) in the presence of steam:

$$
\mathrm{C}+\mathrm{H}_{2} \mathrm{O} \longrightarrow \mathrm{CO}+\mathrm{H}_{2} \quad \text { (Carbon gasification). }
$$

The products $\mathrm{H}_{2}$ and $\mathrm{CO}$ from the aforementioned reactions can be further oxidized by the oxygen carriers to form $\mathrm{CO}_{2}$ and $\mathrm{H}_{2} \mathrm{O}$. Therefore, addition of steam to the fuels can significantly reduce the carbon formation in CLC. The addition of water vapor resulted in the formation of $\mathrm{CO}$ and $\mathrm{H}_{2}$ as intermediate products. Sometimes, some of the intermediate gases will not be completely oxidized by the oxygen carriers leading to an increase of their concentration in the outlet gas from fuel reactor.

Cho et al. [20] investigated the carbon formation conditions on oxygen carriers based on nickel oxide and iron oxide. It was observed that the carbon formation of nickel oxide was considerably affected by the availability of oxygen. Carbon formation was not obvious when sufficient oxygen in the nickel-base oxygen carrier was still available regardless with or without steam addition. For CLR, carbon deposition could be more of a problem since the fuel reactor would be operated under more reducing conditions. For the particles of iron oxide, there was no or very little carbon was formed. Jin et al. [14] reported that carbon deposition of $\mathrm{NiO} / \mathrm{YSZ}$ oxygen carrier can be completely avoided by doping $\mathrm{CoO}$ into the NiO/YSZ. This suggests that carbon formation is also affected by the chemical nature of the oxygen carriers in addition to the operating conditions such as temperature, pressure, gas composition, and particle size.

Basically, carbon formation should not be a problem under the conditions used in a CLC system where a high conversion rate of the fuel is achieved. For a temperature of $950^{\circ} \mathrm{C}$, no carbon formation is expected as long as more than one-fourth of the oxygen needed for complete oxidation of $\mathrm{CH}_{4}$ is supplied [17]. If the CLC process is operated at desired conditions, and a percentage of steam or $\mathrm{CO}_{2}$ is added into the fuels, carbon formation is considerably inhibited.

\section{Conclusions}

CLC is a novel promising technology for fossil fuels conversion with inherent $\mathrm{CO}_{2}$ separation. Extensive research has been performed on CLC in the last decade with respect to oxygen carrier development, reaction kinetics, reactor design, system efficiencies, and prototype testing. Ni, Fe, $\mathrm{Cu}, \mathrm{Mn}$, and $\mathrm{Co}$ oxides are potential candidates for reactive species in the oxygen carrier particles. Ni-based oxygen carriers exhibited the best reactivity and stability during multiredox cycles among these oxides. However, carbon formation is easily generated on Ni-based oxygen carriers when carbon-containing fuels are used in CLC. Doping an impurity such as $\mathrm{CoO}$ into the $\mathrm{NiO}$, and adding a proportion of steam into the fuels can considerably inhibit the carbon formation in the reduction period. The performance of other oxygen carriers above mentioned can be improved by changing preparation method or by making mixed oxides.

The CLC process has been demonstrated successfully both in bench scale fixed-bed reactors and in continuously operated prototype reactors based on interconnected fluidized-bed system in the size range of $0.3-140 \mathrm{~kW}$ using various types of oxygen carriers and different fuels. In these previous investigations, very high fuel conversion rates up to $100 \%$ were achieved in most cases. Therefore, $\mathrm{CO}_{2}$ capture efficiencies were close to $100 \%$. Although there are several approaches to design the CLC reactor system, it is likely that the interconnected fluidized-bed reactors are considered to be the most suitable reactor design.

In recent years, CLR using the same basic principles as CLC has been proposed to generate synthesis gas by partially oxidizing the natural gas or methane with oxygen carriers in fuel reactor. $\mathrm{CLH}$ has been presented to produce pure $\mathrm{H}_{2}$ with $\mathrm{CO}_{2}$ capture by means of water splitting process with a redox of an oxygen carrier. Both CLR and CLH have been demonstrated to be feasible in laboratory scale fluidizedbed reactors. In order to adapt to the characterizations of solid fuels, CLOU, which originates from normal CLC, was proposed to burn solid fuels such as coal, petroleum coke, and biomass.

Despite CLC has attracted extensive research in recent years, there are still a number of issues that require further investigation. For example, development of oxygen carriers with excellent reactivity and stability is still one of the challenges for CLC. Construction and operation of largescale CLC systems is needed before this technology is used 
commercially. As novel techniques of producing synthesis gas and hydrogen using chemical-looping process, CLR and CLH deserve further research in the near future.

\section{Acknowledgment}

The financial support of National Natural Science Foundation of China (50574046 and 50774038) is gratefully acknowledged. This work was also supported by the Director Foundation of Guangzhou Institute of Energy Conversion (0807z2 and o807rf), Chinese Academy of Sciences.

\section{References}

[1] http://topics.nytimes.com/topics/news/science/topics/globalwarming/index.html.

[2] G. A. Florides and P. Christodoulides, "Global warming and carbon dioxide through sciences," Environment International, vol. 35, no. 2, pp. 390-401, 2009.

[3] P. Cho, T. Mattisson, and A. Lyngfelt, "Defluidization conditions for a fluidized bed of iron oxide-, nickel oxide-, and manganese oxide-containing oxygen carriers for chemicallooping combustion," Industrial and Engineering Chemistry Research, vol. 45, no. 3, pp. 968-977, 2006.

[4] A. Lyngfelt, B. Leckner, and T. Mattisson, "A fluidized-bed combustion process with inherent $\mathrm{CO}_{2}$ separation; application of chemical-looping combustion," Chemical Engineering Science, vol. 56, no. 10, pp. 3101-3113, 2001.

[5] F. He, H. Wang, and Y.-N. Dai, "Thermodynamic analysis and experimental investigation into nonflame combustion technology (NFCT) with thermal cyclic carrier," Chemical Research in Chinese Universities, vol. 20, no. 5, pp. 612-616, 2004.

[6] M. Ishida and H. Jin, "A novel chemical-looping combustor without $\mathrm{NO}_{\mathrm{x}}$ formation," Industrial and Engineering Chemistry Research, vol. 35, no. 7, pp. 2469-2472, 1996.

[7] H. J. Richter and K. F. Knoche, "Reversibility of combustion processes," in Efficiency and Costing: Second Law Analysis of Processes, vol. 235 of ACS Symposium Series, pp. 71-85, 1983.

[8] J. Adánez, L. F. de Diego, F. García-Labiano, P. Gayán, A. Abad, and J. M. Palacios, "Selection of oxygen carriers for chemical-looping combustion," Energy and Fuels, vol. 18, no. 2, pp. 371-377, 2004.

[9] P. Gayán, L. F. de Diego, F. García-Labiano, J. Adánez, A. Abad, and C. Dueso, "Effect of support on reactivity and selectivity of Ni-based oxygen carriers for chemical-looping combustion," Fuel, vol. 87, no. 12, pp. 2641-2650, 2008.

[10] H. Jin and M. Ishida, "Reactivity study on natural-gasfueled chemical-looping combustion by a fixed-bed reactor," Industrial and Engineering Chemistry Research, vol. 41, no. 16, pp. 4004-4007, 2002.

[11] M. Ishida, H. Jin, and T. Okamoto, "Kinetic behavior of solid particle in chemical-looping combustion: suppressing carbon deposition in reduction," Energy and Fuels, vol. 12, no. 2, pp. 223-229, 1998.

[12] M. Ishida, H. Jin, and T. Okamoto, "A fundamental study of a new kind of medium material for chemical-looping combustion," Energy and Fuels, vol. 10, no. 4, pp. 958-963, 1996.

[13] H. Jin, T. Okamoto, and M. Ishida, "Development of a novel chemical-looping combustion: synthesis of a solid looping material of $\mathrm{NiO} / \mathrm{NiAl}_{2} \mathrm{O}_{4}$," Industrial and Engineering Chemistry Research, vol. 38, no. 1, pp. 126-132, 1999.
[14] H. Jin, T. Okamoto, and M. Ishida, "Development of a novel chemical-looping combustion: synthesis of a looping material with a double metal oxide of CoO-NiO," Energy and Fuels, vol. 12, no. 6, pp. 1272-1277, 1998.

[15] M. Ishida, M. Yamamoto, and T. Ohba, "Experimental results of chemical-looping combustion with $\mathrm{NiO} / \mathrm{NiAl}_{2} \mathrm{O}_{4}$ particle circulation at $1200^{\circ} \mathrm{C}$," Energy Conversion and Management, vol. 43, no. 9-12, pp. 1469-1478, 2002.

[16] H. Zhao, L. Liu, B. Wang, D. Xu, L. Jiang, and C. Zheng, "Sol-gel-derived $\mathrm{NiO} / \mathrm{NiAl}_{2} \mathrm{O}_{4}$ oxygen carriers for chemicallooping combustion by coal char," Energy and Fuels, vol. 22, no. 2, pp. 898-905, 2008.

[17] T. Mattisson, M. Johansson, and A. Lyngfelt, "The use of $\mathrm{NiO}$ as an oxygen carrier in chemical-looping combustion," Fuel, vol. 85, no. 5-6, pp. 736-747, 2006.

[18] J. E. Readman, A. Olafsen, J. B. Smith, and R. Blom, "Chemical looping combustion using $\mathrm{NiO} / \mathrm{NiAl}_{2} \mathrm{O}_{4}$ : mechanisms and kinetics of reduction-oxidation (Red-Ox) reactions from in situ powder X-ray diffraction and thermogravimetry expirements," Energy and Fuels, vol. 20, no. 4, pp. 1382-1387, 2006.

[19] P. Cho, T. Mattisson, and A. Lyngfelt, "Defluidization conditions for a fluidized bed of iron oxide-, nickel oxide-, and manganese oxide-containing oxygen carriers for chemicallooping combustion," Industrial and Engineering Chemistry Research, vol. 45, no. 3, pp. 968-977, 2006.

[20] P. Cho, T. Mattisson, and A. Lyngfelt, "Carbon formation on nickel and iron oxide-containing oxygen carriers for chemical-looping combustion," Industrial and Engineering Chemistry Research, vol. 44, no. 4, pp. 668-676, 2005.

[21] P. Gayán, L. F. de Diego, F. García-Labiano, J. Adánez, A. Abad, and C. Dueso, "Effect of support on reactivity and selectivity of Ni-based oxygen carriers for chemical-looping combustion," Fuel, vol. 87, no. 12, pp. 2641-2650, 2008.

[22] M. Johansson, T. Mattisson, and A. Lyngfelt, "Using of $\mathrm{NiO} / \mathrm{NiAl}_{2} \mathrm{O}_{4}$ particles in a $10 \mathrm{~kW}$ chemical-looping combustor," Industrial \& Engineering Chemistry Research, vol. 45, pp. 5911-5919, 2006.

[23] R. Villa, C. Cristiani, G. Groppi, et al., "Ni based mixed oxide materials for $\mathrm{CH}_{4}$ oxidation under redox cycle conditions," Journal of Molecular Catalysis A, vol. 204-205, pp. 637-646, 2003.

[24] J. Wolf, M. Anheden, and J. Yan, "Comparison of nickel- and iron-based oxygen carriers in chemical looping combustion for $\mathrm{CO}_{2}$ capture in power generation," Fuel, vol. 84, no. 7-8, pp. 993-1006, 2005.

[25] H.-B. Zhao, L.-M. Liu, D. Xu, C.-G. Zheng, G.-J. Liu, and L.L. Jiang, " $\mathrm{NiO} / \mathrm{NiAl}_{2} \mathrm{O}_{4}$ oxygen carriers prepared by sol-gel for chemical-looping combustion fueled by gas," Journal of Fuel Chemistry and Technology, vol. 36, no. 3, pp. 261-266, 2008.

[26] C. Linderholm, A. Abad, T. Mattisson, and A. Lyngfelt, " $160 \mathrm{~h}$ of chemical-looping combustion in a $10 \mathrm{~kW}$ reactor system with a NiO-based oxygen carrier," International Journal of Greenhouse Gas Control, vol. 2, no. 4, pp. 520-530, 2008.

[27] Q. Zafar, T. Mattisson, and B. Gevert, "Redox investigation of some oxides of transition-state metals $\mathrm{Ni}, \mathrm{Cu}, \mathrm{Fe}$, and supported on $\mathrm{SiO}_{2}$ and $\mathrm{MgAl}_{2} \mathrm{O}_{4}$," Energy and Fuels, vol. 20, no. 1, pp. 34-44, 2006.

[28] E. Johansson, T. Mattisson, A. Lyngfelt, and H. Thunman, "A $300 \mathrm{~W}$ laboratory reactor system for chemical-looping combustion with particle circulation," Fuel, vol. 85, no. 1011, pp. 1428-1438, 2006. 
[29] Q. Zafar, A. Abad, T. Mattisson, and B. Gevert, "Reaction kinetics of freeze-granulated $\mathrm{NiO} / \mathrm{MgAl}_{2} \mathrm{O}_{4}$ oxygen carrier particles for chemical-looping combustion," Energy and Fuels, vol. 21, no. 2, pp. 610-618, 2007.

[30] M. Johansson, T. Mattisson, A. Lyngfelt, and A. Abad, "Using continuous and pulse experiments to compare two promising nickel-based oxygen carriers for use in chemicallooping technologies," Fuel, vol. 87, no. 6, pp. 988-1001, 2008.

[31] M. Rydén, A. Lyngfelt, and T. Mattisson, "Synthesis gas generation by chemical-looping reforming in a continuously operating laboratory reactor," Fuel, vol. 85, no. 12-13, pp. 1631-1641, 2006.

[32] E. Johansson, T. Mattisson, A. Lyngfelt, and H. Thunman, "Combustion of syngas and natural gas in a $300 \mathrm{~W}$ chemicallooping combustor," Chemical Engineering Research and Design, vol. 84, no. A9, pp. 819-827, 2006.

[33] A. Lyngfelt, M. Johansson, and T. Mattisson, "Chemicallooping combustion: status of development," in Proceedings of the 9th International Conference on Circulating Fluidized Beds (CFB '08), Hamburg, Germany, May 2008.

[34] S. R. Son and S. D. Kim, "Chemical-looping combustion with $\mathrm{NiO}$ and $\mathrm{Fe}_{2} \mathrm{O}_{3}$ in a thermobalance and circulating fluidized bed reactor with double loops," Industrial and Engineering Chemistry Research, vol. 45, no. 8, pp. 2689-2696, 2006.

[35] B. M. Corbella, L. F. de Diego, F. García-Labiano, J. Adánez, and J. M. Palacios, "Characterization study and five-cycle tests in a fixed-bed reactor of titania-supported nickel oxide as oxygen carriers for the chemical-looping combustion of methane," Environmental Science and Technology, vol. 39, no. 15, pp. 5796-5803, 2005.

[36] B. M. Corbella, L. F. de Diego, F. García-Labiano, J. Adánez, and J. M. Palacios, "Performance in a fixed-bed reactor of titania-supported nickel oxide as oxygen carriers for the chemical-looping combustion of methane in multicycle tests," Industrial and Engineering Chemistry Research, vol. 45, no. 1, pp. 157-165, 2006.

[37] Q. Zafar, T. Mattisson, and B. Gevert, "Integrated hydrogen and power production with $\mathrm{CO}_{2}$ capture using chemicallooping reforming-redox reactivity of particles of $\mathrm{CuO}$, $\mathrm{Mn}_{2} \mathrm{O}_{3}, \mathrm{NiO}$, and $\mathrm{Fe}_{2} \mathrm{O}_{3}$ using $\mathrm{SiO}_{2}$ as a support," Industrial and Engineering Chemistry Research, vol. 44, no. 10, pp. 34853496, 2005.

[38] M. Johansson, Screening of oxygen-carrier particles based on iron-, manganese-, copper and nickel oxides for use in chemicallooping technologies, Ph.D. thesis, Department of Chemical and Biological Engineering, Environmental Inorganic Chemistry, Chalmers University of Technology, Göteborg, Sweden, 2007.

[39] F. García-Labiano, L. F. de Diego, J. Adánez, A. Abad, and P. Gayán, "Reduction and oxidation kinetics of a copperbased oxygen carrier prepared by impregnation for chemicallooping combustion," Industrial and Engineering Chemistry Research, vol. 43, no. 26, pp. 8168-8177, 2004.

[40] A. Abad, J. Adánez, F. García-Labiano, L. F. de Diego, P. Gayán, and J. Celaya, "Mapping of the range of operational conditions for $\mathrm{Cu}-, \mathrm{Fe}-$, and $\mathrm{Ni}$-based oxygen carriers in chemical-looping combustion," Chemical Engineering Science, vol. 62, no. 1-2, pp. 533-549, 2007.

[41] L. F. de Diego, F. García-Labiano, P. Gayán, J. Celaya, J. M. Palacios, and J. Adánez, "Operation of a $10 \mathrm{~kW}_{\text {th }}$ chemicallooping combustor during $200 \mathrm{~h}$ with a $\mathrm{CuO}-\mathrm{Al}_{2} \mathrm{O}_{3}$ oxygen carrier," Fuel, vol. 86, no. 7-8, pp. 1036-1045, 2007.
[42] M. M. Hossain and H. I. de Lasa, "Chemical-looping combustion (CLC) for inherent $\mathrm{CO}_{2}$ separations-a review," Chemical Engineering Science, vol. 63, no. 18, pp. 4433-4451, 2008.

[43] L. F. de Diego, F. García-Labiano, J. Adánez, et al., "Development of Cu-based oxygen carriers for chemical-looping combustion," Fuel, vol. 83, no. 13, pp. 1749-1757, 2004.

[44] T. Mattisson, A. Järdnäs, and A. Lyngfelt, "Reactivity of some metal oxides supported on alumina with alternating methane and oxygen-application for chemical-looping combustion," Energy and Fuels, vol. 17, no. 3, pp. 643-651, 2003.

[45] L. F. de Diego, P. Gayán, F. García-Labiano, J. Celaya, A. Abad, and J. Adánez, "Impregnated $\mathrm{CuO} / \mathrm{Al}_{2} \mathrm{O}_{3}$ oxygen carriers for chemical-looping combustion: avoiding fluidized bed agglomeration," Energy and Fuels, vol. 19, no. 5, pp. 18501856, 2005.

[46] S. Y. Chuang, J. S. Dennis, A. N. Hayhurst, and S. A. Scott, "Development and performance of Cu-based oxygen carriers for chemical-looping combustion," Combustion and Flame, vol. 154, no. 1-2, pp. 109-121, 2008.

[47] J. Adánez, P. Gayán, J. Celaya, L. F. de Diego, F. GarcíaLabiano, and A. Abad, "Chemical looping combustion in a $10 \mathrm{~kW}_{\text {th }}$ prototype using a $\mathrm{CuO} / \mathrm{Al}_{2} \mathrm{O}_{3}$ oxygen carrier: effect of operating conditions on methane combustion," Industrial and Engineering Chemistry Research, vol. 45, no. 17, pp. 60756080, 2006.

[48] B. M. Corbella, L. de Diego, F. García-Labiano, J. Adánez, and J. M. Palacios, "Characterization and performance in a multicycle test in a fixed-bed reactor of silica-supported copper oxide as oxygen carrier for chemical-looping combustion of methane," Energy and Fuels, vol. 20, no. 1, pp. 148-154, 2006.

[49] S. R. Son, K. S. Go, and S. D. Kim, "Thermogravimetric analysis of copper oxide for chemical-looping hydrogen generation," Industrial and Engineering Chemistry Research, vol. 48, no. 1, pp. 380-387, 2009.

[50] T. Mattisson, H. Leion, and A. Lyngfelt, "Chemical-looping with oxygen uncoupling using $\mathrm{CuO} / \mathrm{ZrO}_{2}$ with petroleum coke," Fuel, vol. 88, no. 4, pp. 683-690, 2009.

[51] B. M. Corbella, L. de Diego, F. García, J. Adánez, and J. M. Palacios, "The performance in a fixed bed reactor of copperbased oxides on titania as oxygen carriers for chemicel looping combustion of methane," Energy and Fuels, vol. 19, no. 2, pp. 433-441, 2005.

[52] H. Tian, K. Chaudhari, T. Simonyi, et al., "Chemical-looping combustion of coal-derived synthesis gas over copper oxide oxygen carriers," Energy and Fuels, vol. 22, no. 6, pp. 37443755, 2008.

[53] M. M. Hossain, K. E. Sedor, and H. I. de Lasa, "Co-Ni/ $\mathrm{Al}_{2} \mathrm{O}_{3}$ oxygen carrier for fluidized bed chemical-looping combustion: desorption kinetics and metal-support interaction," Chemical Engineering Science, vol. 62, no. 18-20, pp. 54645472, 2007.

[54] R. J. Copeland, G. Alptekin, M. Cesario, and Y. Gershanovich, "Sorbent energy transfer system (SETS) for $\mathrm{CO}_{2}$ separation with high efficiency," in Proceedings of the 27th International Technical Conference on Coal Utilization \& Fuel Systems, Clearwater, Fla, USA, 2002.

[55] P. Cho, T. Mattisson, and A. Lyngfelt, "Reactivity of iron oxide with methane in a laboratory fluidized bed-application of chemical looping combustion," in Proceedings of the 7th International Conference on Fluidized Bed Combustion, p. 599, Niagara Falls, Canada, 2000.

[56] M. Ishida, K. Takeshita, K. Suzuki, and T. Ohba, "Application of $\mathrm{Fe}_{2} \mathrm{O}_{3}-\mathrm{Al}_{2} \mathrm{O}_{3}$ composite particles as solid looping material 
of the chemical-loop combustor," Energy and Fuels, vol. 19, no. 6, pp. 2514-2518, 2005.

[57] P. Cho, T. Mattisson, and A. Lyngfelt, "Comparison of iron, nickel-, copper- and manganese-based oxygen carriers for chemical-looping combustion," Fuel, vol. 83, no. 9, pp. 12151225, 2004.

[58] T. Mattisson, M. Johansson, and A. Lyngfelt, "Multicycle reduction and oxidation of different types of iron oxide particles-application to chemical-looping combustion," Energy and Fuels, vol. 18, no. 3, pp. 628-637, 2004.

[59] F. He, H. Wang, and Y. Dai, "Application of $\mathrm{Fe}_{2} \mathrm{O}_{3} / \mathrm{Al}_{2} \mathrm{O}_{3}$ composite particles as oxygen carrier of chemical looping combustion," Journal of Natural Gas Chemistry, vol. 16, no. 2, pp. 155-161, 2007.

[60] A. Abad, T. Mattisson, A. Lyngfelt, and M. Johansson, "The use of iron oxide as oxygen carrier in a chemical-looping reactor," Fuel, vol. 86, no. 7-8, pp. 1021-1035, 2007.

[61] M. Johansson, T. Mattisson, and A. Lyngfelt, "Investigation of $\mathrm{Fe}_{2} \mathrm{O}_{3}$ with $\mathrm{MgAl}_{2} \mathrm{O}_{4}$ for chemical-looping combustion," Industrial and Engineering Chemistry Research, vol. 43, no. 22, pp. 6978-6987, 2004.

[62] H. Leion, T. Mattisson, and A. Lyngfelt, "The use of petroleum coke as fuel in chemical-looping combustion," Fuel, vol. 86, no. 12-13, pp. 1947-1958, 2007.

[63] B. M. Corbella and J. M. Palacios, "Titania-supported iron oxide as oxygen carrier for chemical-looping combustion of methane," Fuel, vol. 86, no. 1-2, pp. 113-122, 2007.

[64] H. Leion, A. Lyngfelt, M. Johansson, E. Jerndal, and T. Mattisson, "The use of ilmenite as an oxygen carrier in chemicallooping combustion," Chemical Engineering Research and Design, vol. 86, no. 9, pp. 1017-1026, 2008.

[65] N. Berguerand and A. Lyngfelt, "The use of petroleum coke as fuel in a $10 \mathrm{~kW}_{\text {th }}$ chemical-looping combustor," International Journal of Greenhouse Gas Control, vol. 2, no. 2, pp. 169-179, 2008.

[66] T. Mattisson, A. Lyngfelt, and P. Cho, "The use of iron oxide as an oxygen carrier in chemical-looping combustion of methane with inherent separation of $\mathrm{CO}_{2}$," Fuel, vol. 80, no. 13, pp. 1953-1962, 2001.

[67] M. Johansson, T. Mattisson, and A. Lyngfelt, "Investigation of $\mathrm{Mn}_{3} \mathrm{O}_{4}$ with stabilized $\mathrm{ZrO}_{2}$ for chemical-looping combustion," Chemical Engineering Research and Design, vol. 84, no. A9, pp. 807-818, 2006.

[68] A. Abad, T. Mattisson, A. Lyngfelt, and M. Rydén, "Chemicallooping combustion in a $300 \mathrm{~W}$ continuously operating reactor system using a manganese-based oxygen carrier," Fuel, vol. 85, no. 9, pp. 1174-1185, 2006.

[69] Q. Zafar, A. Abad, T. Mattisson, B. Gevert, and M. Strand, "Reduction and oxidation kinetics of $\mathrm{Mn}_{3} \mathrm{O}_{4} / \mathrm{Mg}-\mathrm{ZrO}_{2}$ oxygen carrier particles for chemical-looping combustion," Chemical Engineering Science, vol. 62, no. 23, pp. 6556-6567, 2007.

[70] F. He, H. Wang, and Y.-N. Dai, "Preparation and characterization of $\mathrm{La}_{0.8} \mathrm{Cu}_{0.2} \mathrm{MnO}_{(3 \pm \delta)}$ perovskite-type catalyst for methane combustion," Transactions of Nonferrous Metals Society of China, vol. 15, no. 3, pp. 691-696, 2005.

[71] J. E. Readman, A. Olafsen, Y. Larring, and R. Blom, " $\mathrm{La}_{0.8} \mathrm{Sr}_{0.2} \mathrm{Co}_{0.2} \mathrm{Fe}_{0.8} \mathrm{O}_{3-\delta}$ as a potential oxygen carrier in a chemical looping type reactor, an in-situ powder X-ray diffraction study," Journal of Materials Chemistry, vol. 15, no. 19, pp. 1931-1937, 2005.

[72] M. Rydén, A. Lyngfelt, T. Mattisson, D. Chen, A. Holmen, and E. Bjørgum, "Novel oxygen-carrier materials for chemical-looping combustion and chemical-looping reform- ing; $\mathrm{La}_{x} \mathrm{Sr}_{1-x} \mathrm{Fe}_{y} \mathrm{Co}_{1-y} \mathrm{O}_{3-\delta}$ perovskites and mixed-metal oxides of $\mathrm{NiO}, \mathrm{Fe}_{2} \mathrm{O}_{3}$ and $\mathrm{Mn}_{3} \mathrm{O}_{4}$," International Journal of Greenhouse Gas Control, vol. 2, no. 1, pp. 21-36, 2008.

[73] J. Adánez, F. García-Labiano, L. F. de Diego, P. Gayán, J. Celaya, and A. Abad, "Nickel-copper oxygen carriers to reach zero $\mathrm{CO}$ and $\mathrm{H}_{2}$ emissions in chemical-looping combustion," Industrial and Engineering Chemistry Research, vol. 45, no. 8, pp. 2617-2625, 2006.

[74] M. M. Hossain and H. I. de Lasa, "Reactivity and stability of Co-Ni/ $\mathrm{Al}_{2} \mathrm{O}_{3}$ oxygen carrier in multicycle CLC," AIChE Journal, vol. 53, no. 7, pp. 1817-1829, 2007.

[75] M. Johansson, T. Mattisson, and A. Lyngfelt, "Creating a synergy effect by using mixed oxides of iron- and nickel oxides in the combustion of methane in a chemical-looping combustion reactor," Energy and Fuels, vol. 20, no. 6, pp. 2399-2407, 2006.

[76] Q. Song, R. Xiao, Z. Deng, et al., "Chemical-looping combustion of methane with $\mathrm{CaSO}_{4}$ oxygen carrier in a fixed bed reactor," Energy Conversion and Management, vol. 49, no. 11, pp. 3178-3187, 2008.

[77] Q. Song, R. Xiao, Z. Deng, W. Zheng, L. Shen, and J. Xiao, "Multicycle study on chemical-looping combustion of simulated coal gas with a $\mathrm{CaSO}_{4}$ oxygen carrier in a fluidized bed reactor," Energy and Fuels, vol. 22, no. 6, pp. 3661-3672, 2008.

[78] H. Tian, Q. Guo, and J. Chang, "Investigation into decomposition behavior of $\mathrm{CaSO}_{4}$ in chemical-looping combustion," Energy and Fuels, vol. 22, no. 6, pp. 3915-3921, 2008.

[79] L. Shen, M. Zheng, J. Xiao, and R. Xiao, "A mechanistic investigation of a calcium-based oxygen carrier for chemical looping combustion," Combustion and Flame, vol. 154, no. 3, pp. 489-506, 2008.

[80] T. Mattisson, Q. Zafar, M. Johansson, and A. Lyngfelt, "Chemical-looping combustion as a new $\mathrm{CO}_{2}$ management technology," in Proceedings of the 1st Reginal Symposium on Carbon Management, Dhahran, Saudi-Arabia, May 2006.

[81] A. Lyngfelt and H. Thunman, "Construction and $100 \mathrm{~h}$ of operational experience of a $10-\mathrm{kW}$ chemical-looping combustor," in Carbon Dioxide Capture for Storage in Deep Geologic Formations-Results from the $\mathrm{CO}_{2}$ Capture Project, vol. 1, pp. 625-645, 2005.

[82] B. Kronberger, A. Lyngfelt, G. Löffler, and H. Hofbauer, "Design and fluid dynamic analysis of a bench-scale combustion system with 2 separation-chemical-looping combustion," Industrial and Engineering Chemistry Research, vol. 44, no. 3, pp. 546-556, 2005.

[83] B. Kronberger, E. Johansson, G. Löffer, T. Mattisson, A. Lyngfelt, and H. Hofbauer, "A two-compartment fluidized bed reactor for 2 capture by chemical-looping combustion," Chemical Engineering and Technology, vol. 27, no. 12, pp. 1318-1326, 2004.

[84] N. Berguerand and A. Lyngfelt, "Design and operation of a $10 \mathrm{~kW}_{\text {th }}$ chemical-looping combustor for solid fuels — testing with South African coal," Fuel, vol. 87, no. 12, pp. 2713-2726, 2008.

[85] P. Kolbitsch, T. Pröll, J. Bolhar-Nordenkampf, and $H$. Hofbauer, "Operating experience with chemical looping combustion in a $120 \mathrm{~kW}$ dual circulating fluidized bed (DCFB) unit," Energy Procedia, vol. 1, no. 1, pp. 1465-1472, 2009.

[86] J. Bolhàr-Nordenkampf, T. Pröll, P. Kolbitsch, and H. Hofbauer, "Performance of a NiO-based oxygen carrier for chemical looping combustion and reforming in a $120 \mathrm{~kW}$ unit," Energy Procedia, vol. 1, no. 1, pp. 19-25, 2009. 
[87] P. Kolbitsch, J. Bolhàr-Nordenkampf, T. Pröll, and H. Hofbauer, "Comparison of two Ni-based oxygen carriers for chemical looping combustion of natural gas in $140 \mathrm{~kW}$ continuous looping operation," Industrial and Engineering Chemistry Research, vol. 48, no. 11, pp. 5542-5547, 2009.

[88] C. Linderholm, T. Mattisson, and A. Lyngfelt, "Longterm integrity testing of spray-dried particles in a $10-\mathrm{kW}$ chemical-looping combustor using natural gas as fuel," Fuel, vol. 88, no. 11, pp. 2083-2096, 2009.

[89] L. Shen, J. Wu, J. Xiao, Q. Song, and R. Xiao, "Chemicallooping combustion of biomass in a $10 \mathrm{~kW}_{\text {th }}$ reactor with iron oxide as an oxygen carrier," Energy and Fuels, vol. 23, no. 5, pp. 2498-2505, 2009.

[90] H.-J. Ryu and G.-T. Jin, "Conceptual design of $50 \mathrm{~kW}$ thermal chemical-looping combustor and analysis of variables," Journal of Energy Engineering, vol. 12, no. 4, pp. 289-301, 2003.

[91] M. Rydén, A. Lyngfelt, and T. Mattisson, "Chemical-looping combustion and chemical-looping reforming in a circulating fluidized-bed reactor using Ni-based oxygen carriers," Energy and Fuels, vol. 22, no. 4, pp. 2585-2597, 2008.

[92] L. F. de Diego, M. Ortiz, F. García-Labiano, J. Adánez, A. Abad, and P. Gayán, "Synthesis gas generation by chemicallooping reforming using a Ni-based oxygen carrier," Energy Procedia, vol. 1, pp. 3-10, 2009.

[93] L. F. de Diego, M. Ortiz, J. Adánez, F. García-Labiano, A. Abad, and P. Gayán, "Synthesis gas generation by chemicallooping reforming in a batch fluidized bed reactor using Nibased oxygen carriers," Chemical Engineering Journal, vol. 144, no. 2, pp. 289-298, 2008.

[94] L. F. de Diego, M. Ortiz, F. García-Labiano, J. Adánez, A. Abad, and P. Gayán, "Hydrogen production by chemicallooping reforming in a circulating fluidized bed reactor using Ni-based oxygen carriers," Journal of Power Sources, vol. 192, no. 1, pp. 27-34, 2009.

[95] S. R. Son, K. S. Go, and S. D. Kim, "Thermogravimetric analysis of copper oxide for chemical-looping hydrogen generation," Industrial and Engineering Chemistry Research, vol. 48, no. 1, pp. 380-387, 2009.

[96] K. S. Go, S. R. Son, S. D. Kim, K. S. Kang, and C. S. Park, "Hydrogen production from two-step steam methane reforming in a fluidized bed reactor," International Journal of Hydrogen Energy, vol. 34, no. 3, pp. 1301-1309, 2009.

[97] J.-B. Yang, N.-S. Cai, and Z.-S. Li, "Hydrogen production from the steam-iron process with direct reduction of iron oxide by chemical looping combustion of coal char," Energy and Fuels, vol. 22, no. 4, pp. 2570-2579, 2008.

[98] P. Chiesa, G. Lozza, A. Malandrino, M. Romano, and V. Piccolo, "Three-reactors chemical looping process for hydrogen production," International Journal of Hydrogen Energy, vol. 33, no. 9, pp. 2233-2245, 2008.

[99] M. F. Bleeker, H. J. Veringa, and S. R. A. Kersten, "Deactivation of iron oxide used in the steam-iron process to produce hydrogen," Applied Catalysis A, vol. 357, no. 1, pp. 5-17, 2009.

[100] H. Leion, Capture of 2 from solid fuels using chemicallooping combustion and chemical-looping with oxygen uncoupling, Ph.D. thesis, Department of Chemical and Biological Engineering, Environmental Inorganic Chemistry, Chalmers University of Technology, Göteborg, Sweden, 2008.

[101] T. Mattisson, H. Leion, and A. Lyngfelt, "Chemical-looping with oxygen uncoupling using $\mathrm{CuO} / \mathrm{ZrO}_{2}$ with petroleum coke," Fuel, vol. 88, no. 4, pp. 683-690, 2009.

[102] T. Mattisson, A. Lyngfelt, and H. Leion, "Chemical-looping with oxygen uncoupling for combustion of solid fuels,"
International Journal of Greenhouse Gas Control, vol. 3, no. 1, pp. 11-19, 2009.

[103] M. K. Chandel, A. Hoteit, and A. Delebarre, "Experimental investigation of some metal oxides for chemical looping combustion in a fluidized bed reactor," Fuel, vol. 88, no. 5, pp. 898-908, 2009.

[104] E. Jerndal, T. Mattisson, and A. Lyngfelt, "Thermal analysis of chemical-looping combustion," Chemical Engineering Research and Design, vol. 84, no. 9, pp. 795-806, 2006. 

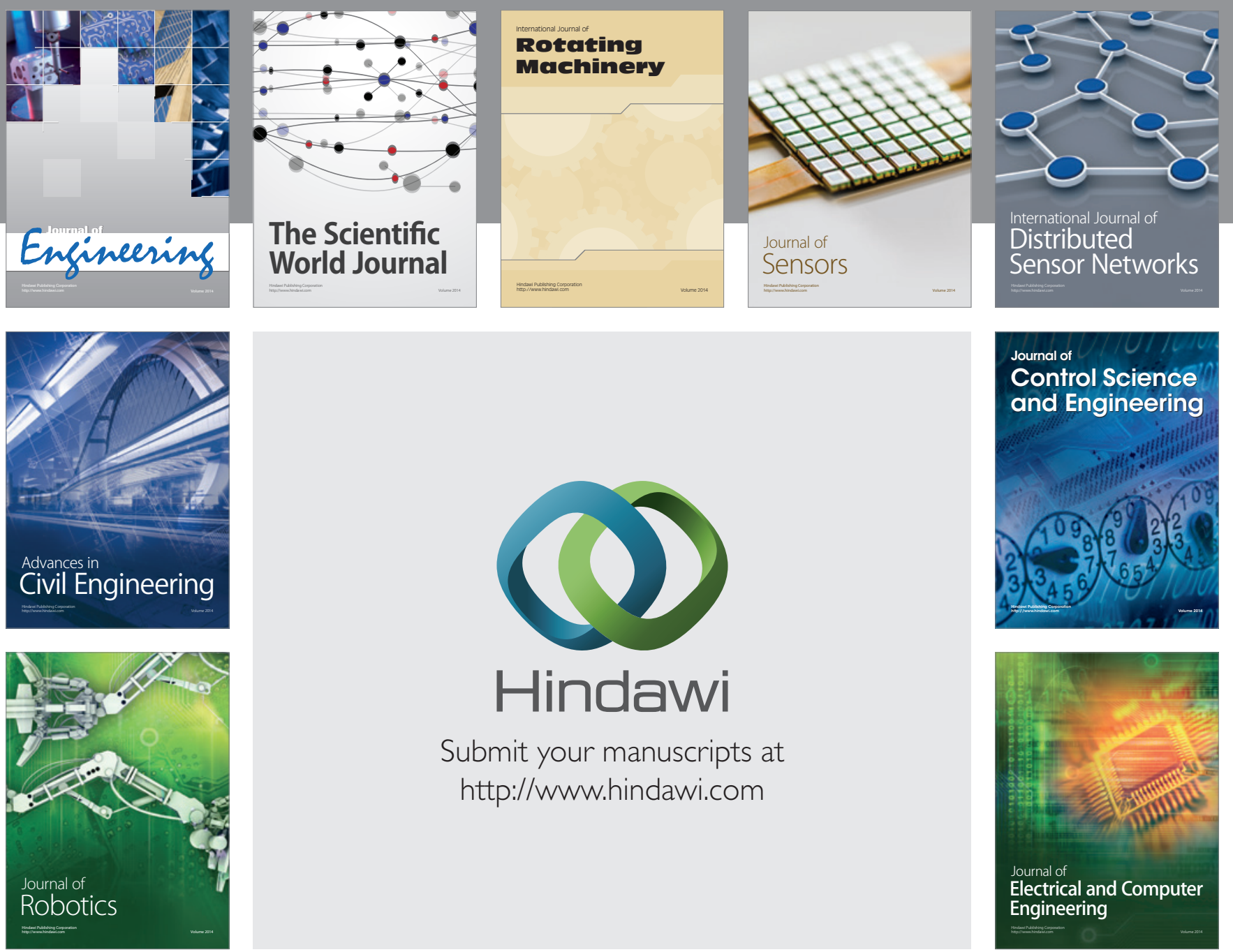

Submit your manuscripts at

http://www.hindawi.com
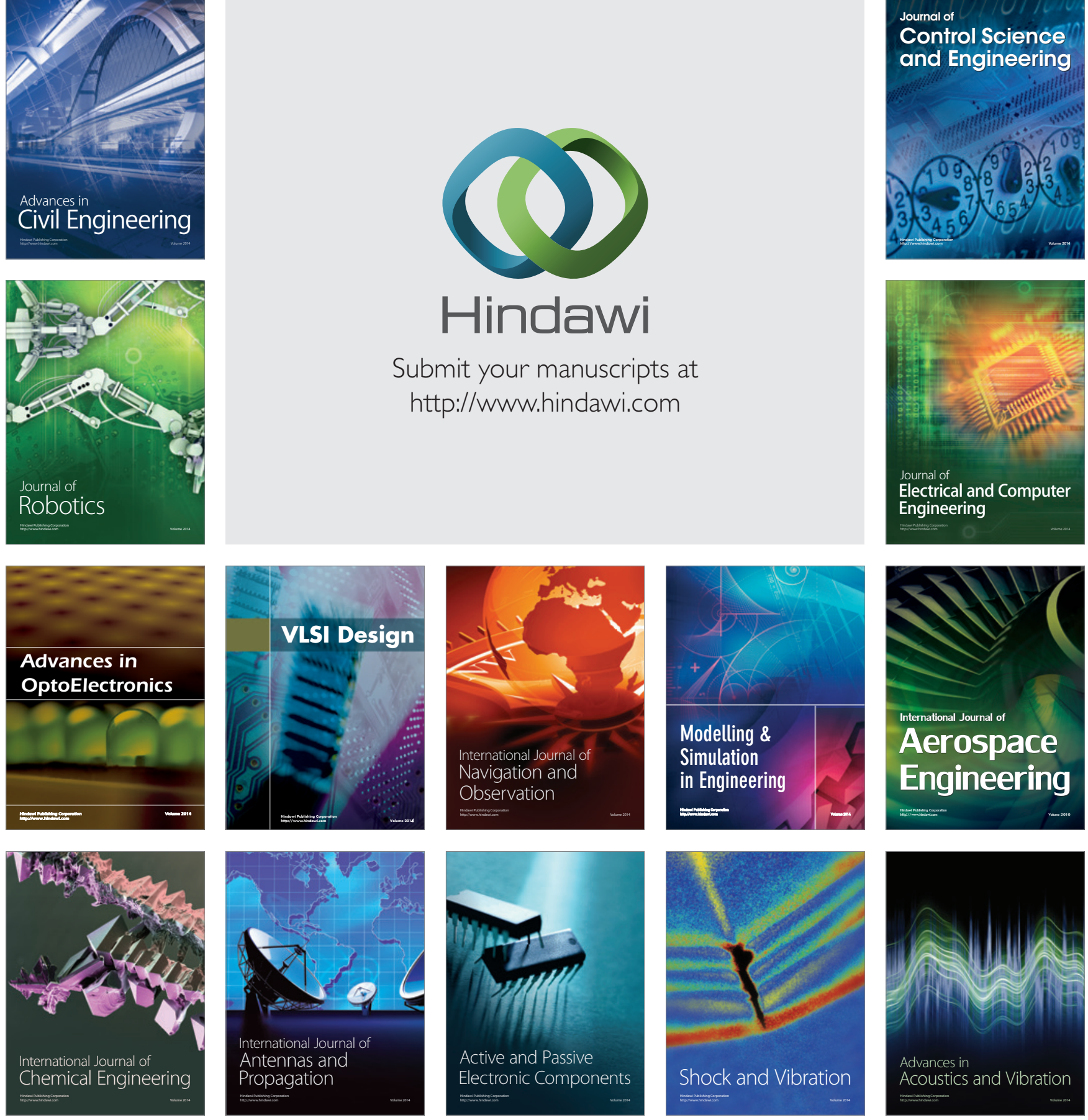